\title{
Glycine and Glycine Receptor Immunoreactivity in Brain and Spinal Cord
}

\author{
Anthony N. van den Pol and Tamas Gorcs' \\ Section of Neurosurgery, Yale University School of Medicine, New Haven, Connecticut 06510, and 'Biomedical Research \\ Center, Tulane University, Belle Chasse, Louisiana 70037
}

To study the distribution of glycine immunoreactive neurons in the spinal cord and brain, antisera were raised against glycine conjugated to protein carriers. High-titer rabbit glyclne antiserum was purified by affinity chromatography. Testing against other amino acids and peptides with immuno dot blots and ELISA assays showed little apparent crossreaction with glutamate, aspartate, glutamine, taurine, and 17 other amino acids and related compounds. Similarly, the antiserum showed little apparent recognition of glycine when glycine was incorporated into peptides. A slight cross-reactivity with GABA, $\beta$-alanine, and cysteine was found. Immunocytochemical labeling of tissue sections could be blocked with glycine conjugated to a heterologous carrier protein but not by other amino acids conjugated to that protein.

Immunocytochemistry at the light microscope level with immunofluorescence and silver-intensified colloidal gold revealed a wide distribution of glycine-like immunoreactivity throughout all laminae of the rat spinal cord and in all segments studied from the cervical, thoracic, lumbar, and sacral cord. Immunoreactive boutons were found terminating on both cell bodies and on dendrites. Ultrastructural analysis with postembedding colloidal gold immunocytochemistry demonstrated large numbers of immunoreactive boutons making symmetrical type synapses with neuronal perikarya, including motor neurons, and with proximal and distal dendrites. Presynaptic glycine immunoreactive boutons were found in both ventral and dorsal horn. Immunoreactivity was concentrated over regions rich in vesicles, and over mitochondria in immunoreactive boutons, but not over mitochondria in postsynaptic dendrites. Glycine-immunoreactive perikarya were identified both in the dorsal horn and in the ventral horn.

Myelinated and unmyelinated glycine-immunoreactive axons were noted both in the gray and white matter of the cord. The density of immunoreactive axons varied in the white matter, with the greatest number of immunoreactive axons found in the white matter adjacent to the gray matter in lateral and ventral white. Significantly fewer immunoreactive axons

\footnotetext{
Received Dec. 29, 1986; revised June 29, 1987; accepted July 29, 1987.

We thank Dr. H. Betz for kindly supplying antisera to the glycine receptor and Dr. R. Wenthold and Dr. R. Pourcho for use of their antisera, and to all three for helpful suggestions. We are also grateful to Ms. Gwen Collins and Dolores Montoya for histological assistance. Supported by research grants NIH NS 16296 and 10174.

Correspondence should be addressed to Anthony N. van den Pol, Section of Neurosurgery, Yale University Medical School, 333 Cedar St., New Haven, CT 06510.

Copyright (C) 1988 Society for Neuroscience $0270-6474 / 88 / 020472-21 \$ 02.00 / 0$
}

were found in the white matter of the dorsal columns. Myelin sheaths around axons were unlabeled.

The distribution of glycine-immunoreactive boutons correlated well with the distribution of glycine receptor immunoreactivity on postsynaptic elements of the spinal cord, tested with different monoclonal antisera against strychninepurified glycine receptor. Glycine receptor immunoreactivity was found throughout the gray matter of both rat and primate. In the white matter, glycine receptor immunoreactivity was absent, except for staining on long dendrites projecting from the gray matter through the ventral and lateral white matter. Ultrastructurally, glycine receptor immunoreactivity was associated with some symmetrical synapses but not with asymmetrical synapses.

Glycine and glycine receptor immunoreactivity were also studied in olfactory bulb, cerebellum, hippocampus, and hypothalamus. In the olfactory bulb, glycine receptor staining was restricted to the external plexiform layer; a few immunoreactive receptors were found in the glomerular layer, and fewer still in the granule cell layer. As in the cord, glycine receptor immunoreactivity in the olfactory bulb was associated with areas of postsynaptic membrane, generally of mitral cells. A diffuse glycine immunoreactivity could be found in the neuropil throughout the bulb; in the glomerular region, a few immunoreactive cells could also be found. Similarly, in the cerebellum, glycine receptor immunoreactivity was found predominantly in the molecular layer, with very little in the granule layer. A few weakly stained glycine-immunoreactive fibers were found in the hippocampus, corresponding to weak staining with glycine receptor antibodies in the area of pyramidal cells and their dendrites.

Taken together with other physiological and pharmacological results, our data support a hypothesis that glycine may be an important neurotransmitter with a widespread distribution throughout all regions of the spinal cord, as well as in selected areas from more rostral regions of the brain.

Glycine, a small neutral amino acid, has been suggested as an inhibitory neurotransmitter that may play a particularly important role in the caudal regions of the CNS, particularly in the spinal cord. That glycine may function as a neurotransmitter is supported by several lines of evidence: An uneven distribution of glycine is found in the vertebrate nervous system, with particularly high concentrations in gray matter of the spinal cord, and strikingly smaller concentrations in the rostral brain (Werman et al., 1967). A high-affinity uptake by active transport has been demonstrated for radiolabeled glycine (Neal, 1971). Strychnine, which in low doses binds selectively to glycine re- 
ceptors (Young and Snyder, 1974), binds to specific regions of the rat nervous system (Zarbin et al., 1981) and to homologous areas of the human nervous system (Probst et al., 1986). Electrophysiological responses to glycine have been recorded, generally of an inhibitory nature (Werman et al., 1967; Curtis et al., 1968), and these can be blocked by strychnine (Curtis et al., 1968; Johnson et al., 1970). Pronounced release of glycine from spinal cord slices, but not from cerebral cortex, can be induced with potassium (Mulder and Snyder, 1974).

In order to study the distribution of cells that contain high concentrations of glycine, and therefore may use it as a neurotransmitter, we have raised rabbit antisera against glycine conjugated to carrier proteins and have used affinity-purified glycine antiserum to study the general distribution of glycine in the spinal cord and selected areas of the brain. Additionally, the ultrastructural localization of glycine immunoreactivity was analyzed with postembedding colloidal gold labeling. We found a much wider distribution of intense glycine immunostaining than we expected, as suggested in a preliminary communication (van den Pol and Gorcs, 1986). To verify that this widespread occurrence of intense immunoreactivity might be related to a role for glycine in neurotransmission, rather than in general metabolism, we also obtained converging evidence by studying glycine receptor distribution. In regions where glycine immunoreactive neurons are found, we compare the distribution of immunoreactive glycine with the immunoreactivity of postsynaptic glycine receptor using monoclonal antibodies produced against the affinity-purified receptor protein (Pfeiffer et al., 1984).

\section{Materials and Methods}

Glycine antisera. Glycine was coupled to either bovine thyroglobulin or keyhole limpet hemocyanin with glutaraldehyde. After extensive dialysis in phosphate buffer, the antigen complex was emulsified in complete Freund's adjuvant and injected subcutaneously and intradermally into rabbits. Additional boosts in incomplete Freund's adjuvant were given at 5-6 week intervals, and blood was collected starting a week after the second boost. Of 4 antisera made, we chose the one with the highest apparent titer, and the most selectivity for glycine, for further analysis. This antiserum was against glycine conjugated to thyroglobulin. The number of molecules of glycine per molecule of thyroglobulin was determined by the use of tritiated glycine (Amersham). A fresh conjugate was made prior to each antigen injection; the molar ratio for the 3 injections given prior to the final bleed used in the present paper was $24: 1,28: 1$, and $25: 1$ (glycine: thyroglobulin).

To test specificity of the rabbit antiserum, we used amino acids conjugated to a different protein than had been used to raise the antibody. Amino acids conjugated to BSA were blotted on nitrocellulose, incubated with glycine antiserum, and stained with biotin, avidin, and HRP conjugates (ABC method of Hsu et al., 1981). These tests indicated that the glycine antiserum did not react with glutamate, glutamine, serine, aspartate, or taurine. A cross-reactivity to alanine, GABA, and $\beta$-alanine was found, in addition to reactivity against the carrier protein used to make the immunogen.

To reduce the cross-reactivity with cross-reacting amino acids, a 2 -step affinity purification was used. BSA was attached to cyanogen bromide-activated Sepharose 4B. Glycine was subsequently conjugated to the BSA with glutaraldehyde. Serum was incubated in the column, the column washed with phosphate buffer, and the affinity-purified antibody eluted first with $0.2 \mathrm{M}$ acetic acid (pH 2.8) and then with $0.2 \mathrm{M}$ sodium carbonate ( $\mathrm{pH}$ 10.5). Both acid and base fractions contained antibody activity; the resultant eluate was passed over another BSASepharose $4 \mathrm{~B}$ column to which GABA and alanine had been conjugated with glutaraldehyde. The protein fraction of the serum that passed through the column was identified with spectrophotometry and saved for specificity analysis and immunocytochemistry.

A solid-phase plastic ELISA assay was also used to test cross-reactivities. BSA (1\%) was adsorbed onto the plastic of 96 -well plates overnight. After incubation in $10 \%$ glutaraldehyde for $15 \mathrm{~min}$, plates were washed with $0.1 \mathrm{M}$ phosphate buffer, and $75 \mu \mathrm{l}$ of $0.1 \mathrm{M}$ concentrations of different amino acids, peptides, or proteins were conjugated to the BSA through glutaraldehyde. Sodium borohydride $(0.5 \%)$ was used to block open aldehyde binding sites, followed by incubation in Tris, ethanolamine, and BSA. After additional rinsing, antisera or affinity-purified antisera were incubated for $2 \mathrm{hr}$. After plates were washed with phosphate buffer, affinity-purified goat anti-rabbit IgG labeled with HRP (Flow Labs) was used at a dilution of 1:12,000. $o$-Phenylenediamine in the presence of hydrogen peroxide was used to detect peroxidase activity. Wells containing possible cross-reactive substances were done in pairs or triplicate, and the mean absorbance value used. Absorbance values for individual wells were read at $492 \mathrm{~nm}$ with a Biorad EIA spectrophotometer linked to a lab computer.

Glycine receptor antisera. Mouse monoclonal antibodies against the affinity-purified rat glycine receptor (Pfeiffer et al., 1982, 1984) were a generous gift of Dr. H. Betz (University of Heidelberg). Glycine receptors were purified by affinity chromatography on a strychnine column as described elsewhere (Pfeiffer et al., 1982). Monoclonal antibody 7 a was used in the present study for much of the immunocytochemistry; of the several tested it gave the lowest background and the strongest signal, and was the least sensitive to aldehyde fixation. Monoclonal antibody $5 \mathrm{a}$, directed against a different determinant on the glycine receptor (Pfeiffer et al., 1984; Triller et al., 1985), was also used to confirm the presence of glycine receptors. Antibodies reacted specifically with strychninepurified glycine receptor, as described previously (Pfeiffer et al., 1984). Both monoclonal antibodies 7a and 5a bind to the 93,000 Da glycine receptor subunit (Pfeiffer et al., 1984; Schmitt et al., 1987). An extensive biochemical characterization of the specificity of the monoclonal antibodies is described elsewhere (Pfeiffer et al., 1984; Triller et al., 1985).

\section{Immunocytochemistry}

Glycine immunostaining. Rats were deeply anesthetized with Nembutal and perfused transcardially with saline followed by $3 \%$ glutaraldehyde for $30 \mathrm{~min}$. The cord was removed and left in fixative for an additional hour. Some tissue blocks were osmicated, and others were not. Tissue was dehydrated and embedded in Epon. One micron semithin sections were cut on a Reichert Ultracut and mounted on albumin-treated glass slides. Epon was removed with a mixture of propylene oxide, methanol, and potassium hydroxide $(5 \mathrm{~min}$ ) (Maxwell, 1978; De Camilli et al., 1983), treated with sodium borohydride to quench reactive glutaraldehyde sites, and if osmicated, reacted with $3 \%$ hydrogen peroxide for 5 min to reduce the osmium presence. Autofluorescence was eliminated with either sodium borohydride, osmium tetroxide, or both.

Primary antiserum in its native state could be used at 1:4000 to $1: 10,000$ for immunostaining of the spinal cord. Affinity-purified antiserum was used at higher concentrations (1:100-1:800). For fluorescent staining, a secondary antibody of goat anti-rabbit immunoglobulin (EY Labs) conjugated to FITC was used at a 1:200 dilution.

For light microscopy, goat secondary antisera adsorbed to 5 or $10 \mathrm{~nm}$ diameter colloidal gold particles were used. As this size gold is not visible with normal light microscopy, the gold was intensified with a silverintensification procedure (SIG) described previously (van den Pol, 1985b, 1986), resulting in black immunolabeled structures.

To examine the ultrastructural localization of glycine immunoreactivity, colloidal gold was used. Tissue was fixed as described above, treated for $1 \mathrm{hr}$ in $1 \%$ osmium tetroxide, and embedded in Epon. Ultrathin sections were cut on a Reichert Ultracut microtome and picked up on nickel or gold grids. Antisera were mixed in Tris-bufferered saline (pH 8.2) with BSA and applied as described elsewhere (van den Pol, 1984, 1985; Somogyi and Hodgson, 1985).

Glycine receptor immunostaining. Under anesthesia, rats were perfused with $4 \%$ paraformaldehyde for $30 \mathrm{~min}$. Cords were removed, left for an additional hour in the fixative, infiltrated with $30 \%$ sucrose for an hour, and frozen. Five micron frozen sections were cut on a freezing microtome and picked up on gelatin-coated glass slides. One micron tissue sections from tissue similarly fixed and embedded in Epon were also used. Prior to immunostaining, Epon was etched as described above. Secondary antisera of FITC-labeled affinity-purified goat anti-mouse IgG from Flow Labs was used at a dilution of 1:100.

For ultrastructural localization of glycine receptor immunoreactivity, tissue was fixed with $4 \%$ paraformaldehyde, and cut in $30 \mu \mathrm{m}$ sections on a Vibratome. To improve antisera penetration into sections, tissue was incubated in $30 \%$ sucrose and then frozen in liquid nitrogen. After incubation in monoclonal antibody, sections were immersed in biotinylated goat anti-mouse immunoglobulin antisera and then stained with peroxidase using the ABC method of Hsu et al. (1981). After treatment 
Table 1. Cross-reactivity of affinity-purified glycine antiserum

\begin{tabular}{|c|c|c|c|c|c|c|c|}
\hline & $100 \%$ & $>50 \%$ & $>10 \%$ & $>5 \%$ & $>1 \%$ & $>0.5 \%$ & $0.3-0 \%$ \\
\hline Alanine & & & & & & & - \\
\hline Alpha-amino butyrate & & & & & & & - \\
\hline Aspartate [D-] & & & & & & & - \\
\hline Aspartate [L-] & & & & & & & - \\
\hline Beta-alanine & & & & & $3 \%$ & & \\
\hline Beta-amino butyrate & & & & & & & - \\
\hline Cysteine & & & & & & $1 \%$ & \\
\hline Ethanolamine & & & & & & & - \\
\hline GABA & & & & & & $1 \%$ & \\
\hline Glutamate [D-] & & & & & & & - \\
\hline Glutamate [L-] & & & & & & & - \\
\hline (Acetyl-) glutamate & & & & & & & - \\
\hline Glutamine & & & & & & & - \\
\hline (Acetyl-) glutamine & & & & & & & - \\
\hline Glycine & $100 \%$ & & & & & & \\
\hline (Acetyl-) glycine & & & & & & & - \\
\hline Lysine & & & & & & & - \\
\hline Methionine & & & & & & & - \\
\hline Phenylalanine & & & & & & & - \\
\hline Proline & & & & & & & - \\
\hline Serine & & & & & & & - \\
\hline Taurine & & & & & & & - \\
\hline Tris & & & & & & & - \\
\hline Tryptophan & & & & & & & - \\
\hline Valine & & & & & & & - \\
\hline \multicolumn{8}{|l|}{ Polyamino acids } \\
\hline Polyaspartate & & & & & & & - \\
\hline Polyglutamate & & & & & & & - \\
\hline Polyglycine & & & & & & & - \\
\hline \multicolumn{8}{|l|}{ Peptides } \\
\hline Alpha-aspartyl glycine & & & & & & & - \\
\hline Beta-aspartyl glycine & & & & & & & - \\
\hline Carnosine & & & & & & & - \\
\hline Glycyl glycyl valine & & & & & & & - \\
\hline Homo-carnosine & & & & & & & - \\
\hline Gamma-glutamyl glutamate & & & & & & & - \\
\hline Gamma-glutamyl glutamine & & & & & & & - \\
\hline Alpha-glutamyl alanine & & & & & & & - \\
\hline
\end{tabular}

with diaminobenzidine and osmication, tissue was dehydrated and flatembedded in Epon; ultrathin sections were then cut.

To compare rodents with primates, spinal cord tissue from an adult female rhasus monkey (gift of Dr. R. Kuljis) was used. Tissue was fixed with $4 \%$ paraformaldehyde, $0.05 \%$ glutaraldehyde, and picric acid (Somogyi and Takagi, 1982). Five micron frozen sections were cut from the midcervical region and immunostained as described above.

\section{Results}

\section{Glycine antiserum characterization}

To examine glycine antibody specificity, we used a test system that paralleled tissue immunocytochemistry. With the EI.ISA assay, glutaraldehyde was used to bind a series of amino acids to protein adsorbed to the plate surface, and after affinity purification, the antiserum appeared to recognize glycine specifically. When paraformaldehyde was substituted for glutaraldehyde, glycine antiserum did not recognize those wells containing glycine; similarly, when spinal cord fixed only with paraformaldehyde was examined, no specific glycine staining was found.
Cross-reactivity of glycine antisera with other amino acids and peptides was tested with the ELISA procedure described above. To increase the sensitivity of detecting well cross-reactions, the orthophenylene diamine reaction was allowed to proceed until all wells exhibited at least a faint coloration. To allow an estimate of cross-reactivity, glycine standards were used. Decreasing concentrations of glycine, each concentration in triplicate, were conjugated to BSA absorbed to wells in the ELISA plate. A percentage of cross-rcactivity was defincd relative to a comparison of the absorbance of $75 \mu \mathrm{l}$ of $0.1 \mathrm{M}$ amino acid to the concentration of glycine that would generate a similar absorbance value. In other words, a $1 \%$ cross-reactivity for GABA would indicate that the absorbance level found for a given molar concentration of glycine would require 100 times more GABA to generate the same absorbance value.

Table 1 shows a number of amino acids and peptides that were tested for cross-reactivity. Most of those tested show little detectable cross-reactivity. Putative neurotransmitter amino 


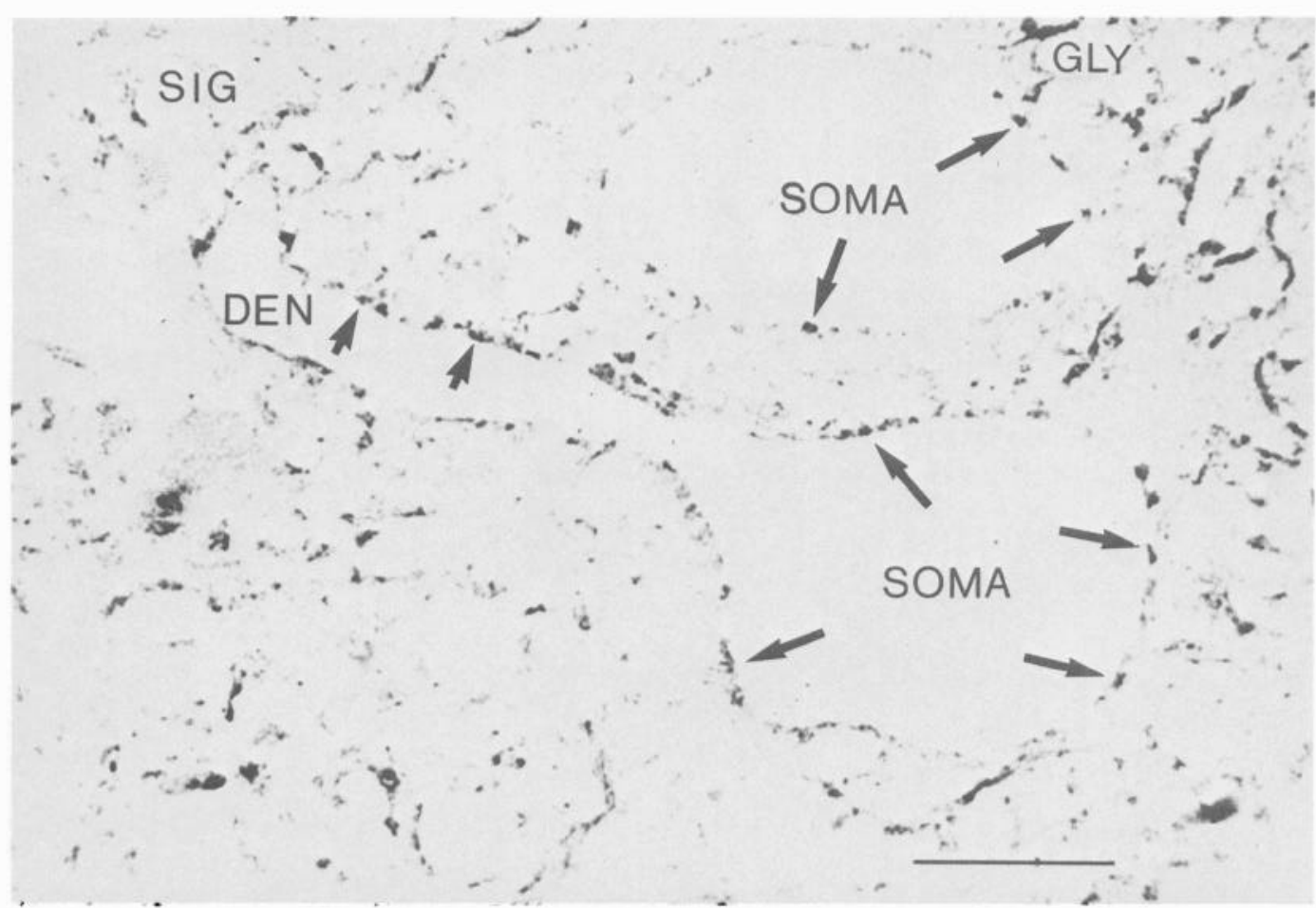

Figure 1. Glycine immunoreactivity $(G L Y)$ in ventral horn. Black glycine immunoreactive boutons and axons are stained with silver-intensified gold $(S I G)$. Strongly immunoreactive boutons cover the dendrites $(D E N)$ and somata $(S O M A)$ of 2 large cells in the cervical cord. Scale bar, $18 \mu \mathrm{m}$.

acids including glutamate, aspartate, and taurine showed no detectable cross-reaction. Even serine, a probable precursor to glycine (Aprison et al., 1975), showed no cross-reaction with the antiserum. The strongest cross-reactivity was with $\beta$-alanine (3\%). We were unable to completely eliminate the $\beta$-alanine cross-reactivity with affinity chromatography without also removing most of the glycine immunoreactivity. The amount of $\beta$-alanine in the spinal cord is extremely low compared with glycine (Curtis et al., 1968) and therefore probably does not constitute a serious complication.

As described below, a number of structures in the spinal cord showed strong immunostaining with antisera against glycine. Substitution of normal rabbit serum or elimination of primary antiserum resulted in lack of staining. When reactive antiserum was passed through a column with glycine conjugated with glutaraldehyde to a different carrier protein (BSA) than was used for immunization, and coupled to a Sepharose 4B column, immunostaining was abolished. Substitution of antisera against peptides (neurophysin, oxytocin, vasopressin) gave very different patterns of staining.

\section{Tissue immunoreactivity-light microscopy}

Spinal cord: gray matter of rat. In all regions of gray matter of the spinal cord, at every level examined, and in all laminae studied, glycine-immunoreactive fibers could be found. The density of immunoreactive fibers varied among different regions of the cord.

Intensely labeled glycine-immunoreactive axons were found surrounding motor neurons in all regions of the cord examined, including cervical, thoracic, lumbar, and sacral segments. Immunoreactive boutons were found closely apposed to the large motor neuron perikarya. Immunoreactive boutons and axons were also seen surrounding the large dendrites of the motor neurons extending away from the soma (Fig. 1). In $500 \mathrm{~nm}$ semithin sections of the ventral horn, single large motor neurons and their proximal dendrites were sometimes contacted by more than 50 glycine-immunoreactive boutons, suggesting that if boutons were counted in serial sections of single cells, some cells would be contacted by hundreds of immunoreactive terminals. Of over a hundred large cells in the motor neuron area in the ventral horn studied with light microscopy, every cell was surrounded by glycine-immunoreactive fibers.

Similar to the immunoreactivity of glycine itself (Fig. 2, A, $B)$, immunoreactive glycine receptors, located with monoclonal antibody $5 \mathrm{a}$ and $7 \mathrm{a}$, were found throughout all laminae of the gray matter of the spinal cord in all segments examined, including cervical, thoracic, lumbar, and sacral. The distribution of the receptor was not homogeneous. As described previously (Triller et al., 1985), glycine receptor immunoreactivity had a very punctate appearance. In the spinal cord, immunoreactive glycine receptors were stained very brightly with immunofluorescence. On thinner sections, immunoreactive receptors surrounded cell bodies and large dendrites, and bright fluorescent patches appeared restricted to a plasmalemmal localization (Fig. $2, C, D)$. Patterns of immunostaining with the monoclonal antibodies $5 \mathrm{a}$ and $7 \mathrm{a}$ were similar. Substitution of mouse immunoglobulin for the specific mouse antibodies resulted in no staining. Just as the density of both immunoreactive glycine and immunoreactive glycine receptor varied in different regions of the cord, the density of labeling at the cellular level varied. Some cells, large and small, appeared to have large numbers of glycine receptors, while others appeared to have only a few punctate densities on the cell body. Similarly, large dendrites sometimes appeared heavily invested with glycine receptors, while others 

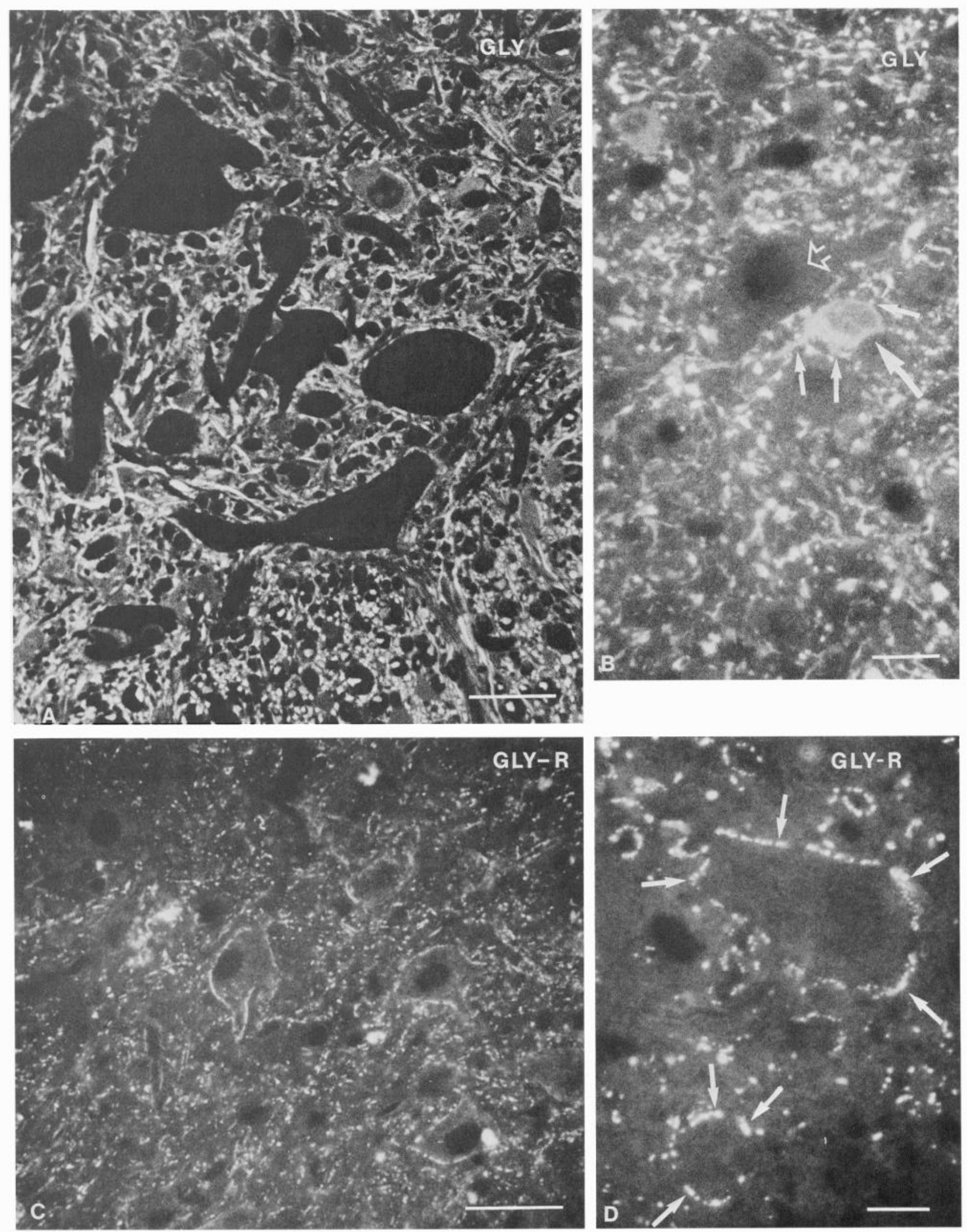

Figure 2. Glycine and glycine receptor immunoreactivity in ventral horn. $A$, White glycine immunoreactivity $(G L Y)$ detected by immunofluorescence in the lumbar region of the cord. Brightly fluorescent fibers are distributed throughout the ventral horn and surround unlabeled large motor neurons. Scale bar, $25 \mu \mathrm{m}$. B. Glycine immunoreactive $(G L Y)$ cell in ventral horn. Adjacent to a large unlabeled neuron (hollow arrow) in the ventral horn, a small fluorescent glycine-immunoreactive cell can be seen (large white arrow). Immunoreactive boutons (small arrows) surround both the large unlabeled cell and the smaller immunoreactive cell. Scale bar, $25 \mu \mathrm{m}$. $C$, Glycine receptor immunoreactivity $(G L Y-R)($ stained with monoclonal antibody $5 \mathrm{a}$ ) has a similar pattern to that found in part $A$, except that the immunoreactivity appears as small patches of immunoreactivity. Scale bar, $50 \mu \mathrm{m} . D$, gly-R immunoreactive patches (arrows) surround the perikarya of 2 neurons. Scale bar, $10 \mu \mathrm{m}$. 

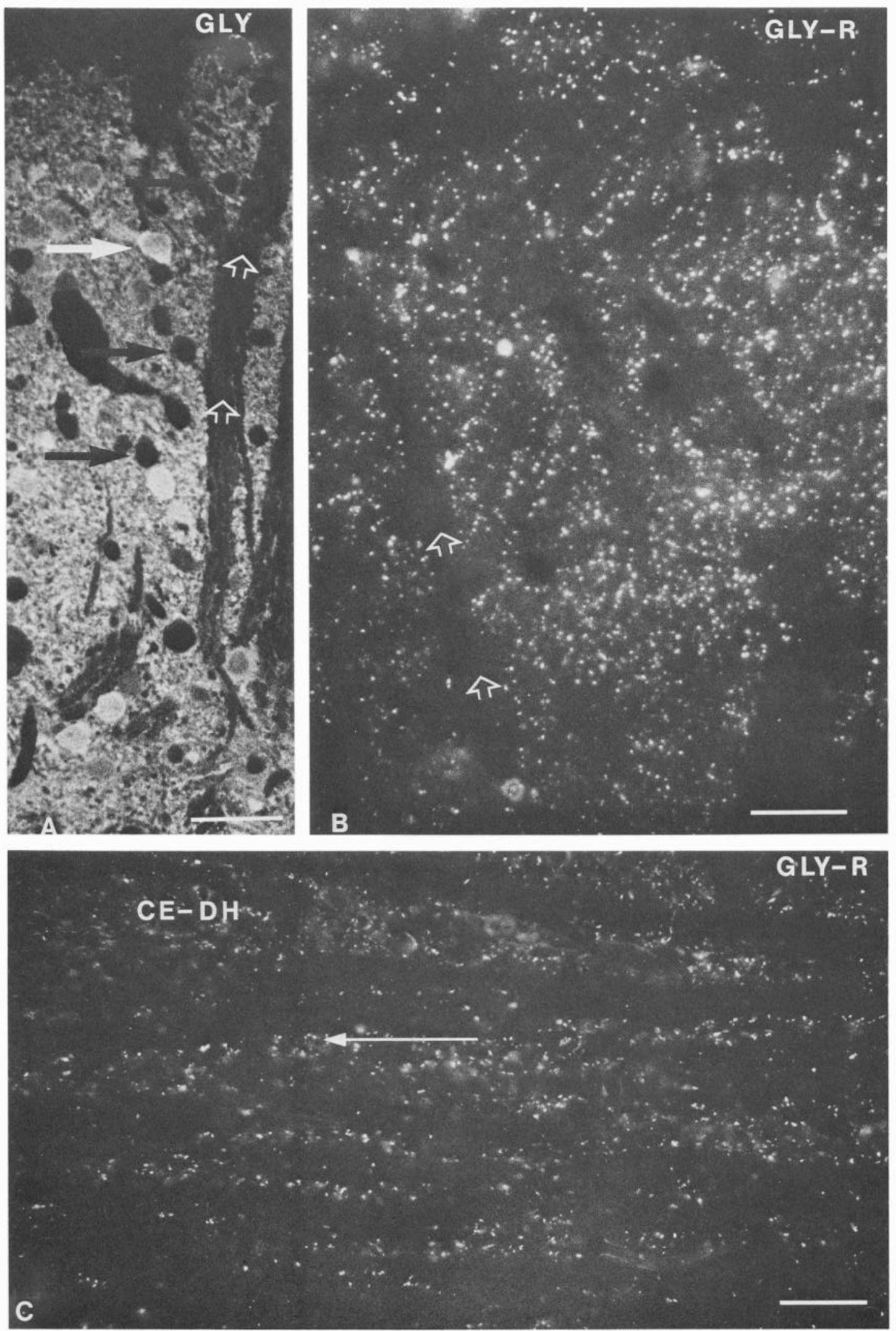

Figure 3. Glycine and glycine receptor immunoreactivity in the midcervical dorsal horn. $A$, Glycine immunoreactivity $(G L Y)$ is found throughout the dorsal horn, with a stronger immunofluorescence in the deeper layers. A few small immunoreactive cells (white arrow) are seen. Immunoreactivity is absent in the incoming dorsal root axons (hollow arrows). Scale bar, $55 \mu \mathrm{m}$. B, Glycine receptor immunoreactivity (GLY-R) shows a similar pattern to that seen with glycine immunostaining, with gly-R immunoreactivity found throughout the dorsal horn with highest densities in the deeper laminae of the dorsal horn. Immunoreactivity is absent in large fascicles of dorsal root fibers (hollow arrows). Scale bar, $30 \mu \mathrm{m}$. $C$, In a horizontal section of the cervical dorsal horn $(C E-D H)$ where dendrites are often found running in a rostrocaudal direction (long white arrow), glycine receptor immunoreactivity is seen dispersed between fascicles of unlabeled myelinated axons. Scale bar, $45 \mu \mathrm{m}$. 

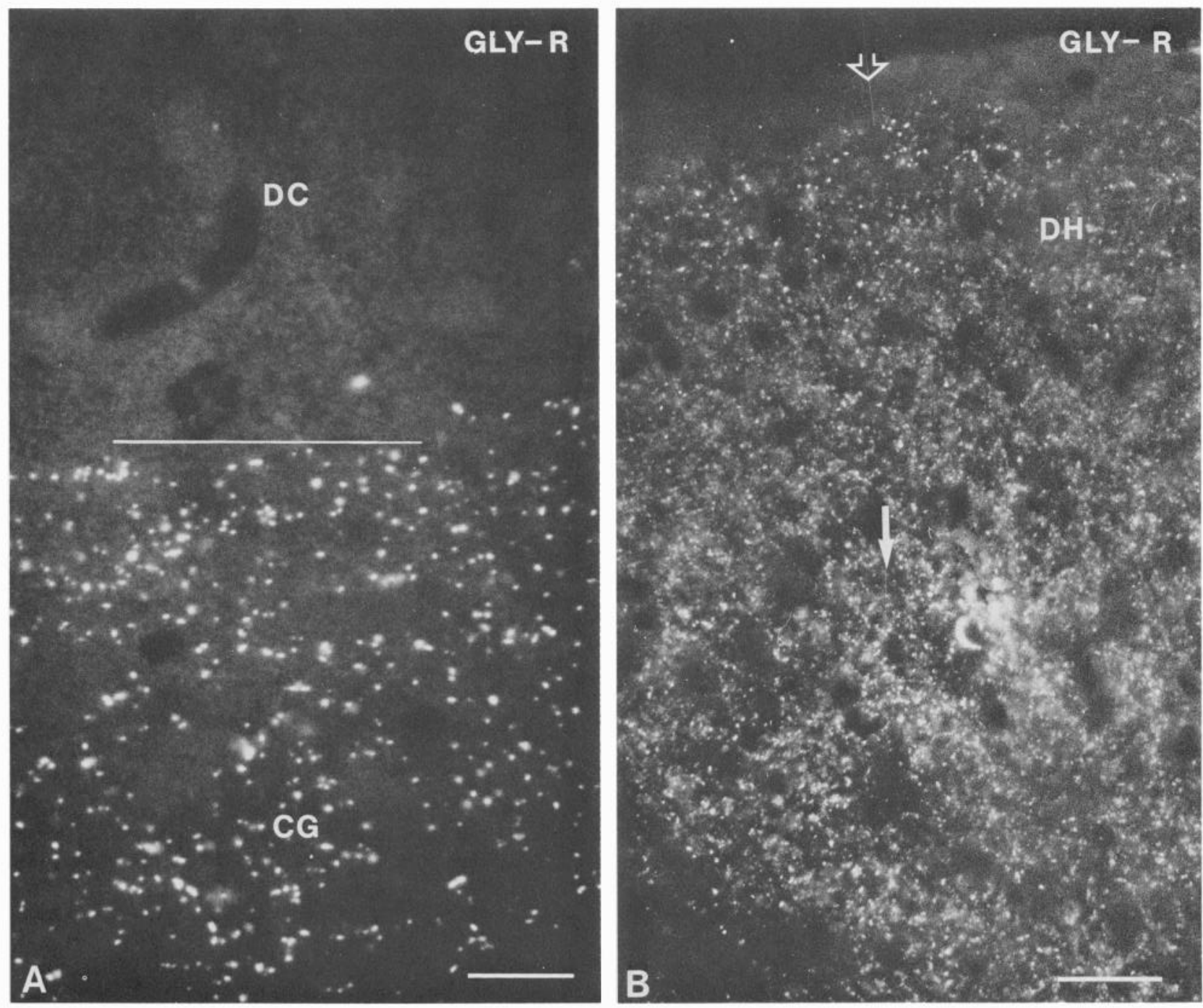

Figure 4. Glycine receptor immunoreactivity. A, Glycine receptor immunoreactivity $(G L Y-R)$ is absent from the dorsal columns (DC) of lumbar cord above the white line. In the central gray matter above the central canal (below white line), large numbers of immunoreactive densities are seen. Scale bar, $10 \mu \mathrm{m} . B$, Glycine receptor immunoreactivity is densest in deeper layers of the dorsal horn (DH; white arrow) but is also found in more superficial laminae to the top of the cord (hollow arrow). Scale bar, $30 \mu \mathrm{m}$.

showed relatively few. The size of the glycine receptor containing postsynaptic membrane also showed a heterogeneity; some regions, particularly the perikaryon of some motor neurons, appeared to have immunoreactive membrane areas extending several microns, while in other regions, notably in laminae 1 and 2 (Rexed, 1954) of the dorsal horn, the size of the receptoroccupied membrane was small $(<0.5 \mu \mathrm{m})$. Ultrastructural verification of the synaptic localization of glycine receptor immunoreactivity is described later.

Occasional immunoreactive cell bodies smaller than the motor neurons were found in the ventral horn near large motor neurons (Fig. $2 B$ ). In the dorsal horn, particularly in deeper laminae, small immunoreactive cells were also found (Fig. $3 A$ ). Immunoreactive cells were less intensely labeled than immunoreactive boutons, and sometimes appeared to be in close proximity to immunoreactive axons (Fig. $3 A$ ). Nuclei of immunoreactive cells were often slightly immunoreactive.

In the dorsal horn of the cord, glycine immunoreactive axons were found in greatest numbers in deeper laminae, but axons were present also in laminae 1 and 2 (Fig. $3 A$ ). Similarly, gly-R immunoreactivity was found in all regions of the dorsal horn, with particularly strong levels of immunoreactivity in the deeper layers of the dorsal horn (cross section: Figs. $3 B$ and $4 B$; horizontal section: Fig. 3C).

Spinal cord: white matter. Individual axons in certain regions of the white matter appeared strongly labeled with both fluorescent and SIG immunocytochemistry. Immunoreactive axons were generally surrounded by unlabeled axons. The density of glycine-immunoreactive axons was the greatest adjacent to the gray matter in the lateral (Fig. 5, $A, B$ ) and ventral white matter (Fig. 6, $B, C$ ) and lowest in the dorsal columns (Fig. 6A). Both large myelinated axons and smaller axons were immunoreactive (Fig. $6 B$ ). That the axonal immunoreactivity was not due to a cross-reaction of our antiserum with $\beta$-alanine (Table 1 ) is shown by staining adjacent section with antisera against glycine or $\beta$-alanine. At similar serum dilutions, staining was seen only with glycine antiserum and not with $\beta$-alanine antiserum (Fig. 5, $C, D$ ). SIG immunostaining of glycine immunoreactivity provided suggestive evidence that the myelin sheaths around axons were not labeled (Fig. $6, A, B$ ). This was confirmed 

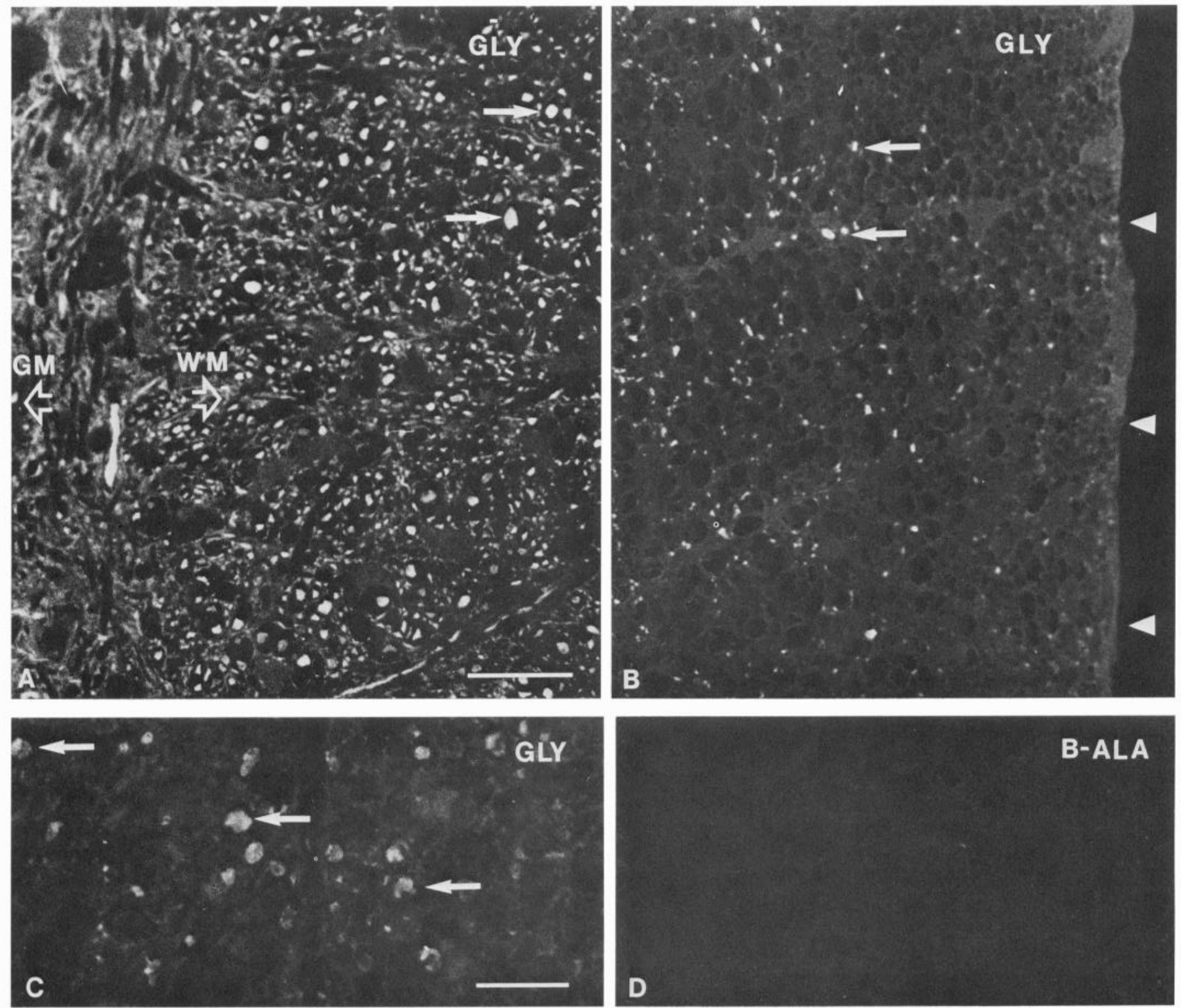

Figure 5. Glycine immunofluorescence in white matter. Two micrographs were made from the same histological section of the cord. $A$, Medial part of the lateral white matter $(W M)$ adjacent to the gray matter $(G M)$. $B$, Lateral part of the lateral white. The number of immunoreactive axons (white arrows) is much greater in the medial part than in the lateral part. The lateral edge of the spinal cord is indicated by the white arrowheads. Antisera against glycine $(C)$ or $\beta$-alanine $(D)$ conjugated to BSA (Chemicon) were compared, with both antisera used at the same concentration $(1: 500)$. Axons are stained with glycine $(G L Y)$ antiserum in $C$, but not with antiserum against $\beta$-alanine $(B$ - $A L A)(D)$ in adjacent serial sections of the ventral white matter in the cervical cord. Scale bars: $A$ and $B, 20 \mu \mathrm{m} ; C$ and $D, 25 \mu \mathrm{m}$.

with ultrastructural examination of glycine immunolabeling in the lateral white matter with colloidal gold (Fig. 6D). High levels of glycine immunoreactivity were not seen in control tissue from the optic tract adjacent to the hypothalamus.

In cross sections of the cord, immunoreactive axons were seen as large or small dots; a few smaller axons could be found leaving the gray matter and projecting radially out of the gray matter. These axons with the radial orientation may have been making synaptic contact with large dendrites which leave the gray matter and receive synaptic contact from axons in the white matter. This was supported by glycine receptor immunostaining; large dendrites, particularly in the ventrolateral and lateral white matter could be found with punctate immunostaining. While gly-R immunoreactivity was strongest near the gray core of the spinal cord, it could also be found on dendrites which stretched across the entire white matter and ended near the peripheral border of the cord. These gly-R-immunoreactive dendrites were found in the cervical (Fig. 7A), thoracic (Fig. 7B), lumbar, and sacral regions of the cord. Gly-R immunoreactivity was notably absent in the dorsal columns; this contrasted with the gray matter between the dorsal column and central canal, which was rich in glycine receptors (Fig. 4A).

Neither glycine (Fig. $3 A$ ) nor glycine receptor (Fig. $3 B$ ) immunoreactivity was found in the dorsal roots entering into the dorsal laminae. Similarly, both were absent from the ventral roots leaving the gray matter and traversing the ventral white matter (Fig. 6C).

Staining patterns of spinal cord sections immunocytochem- 

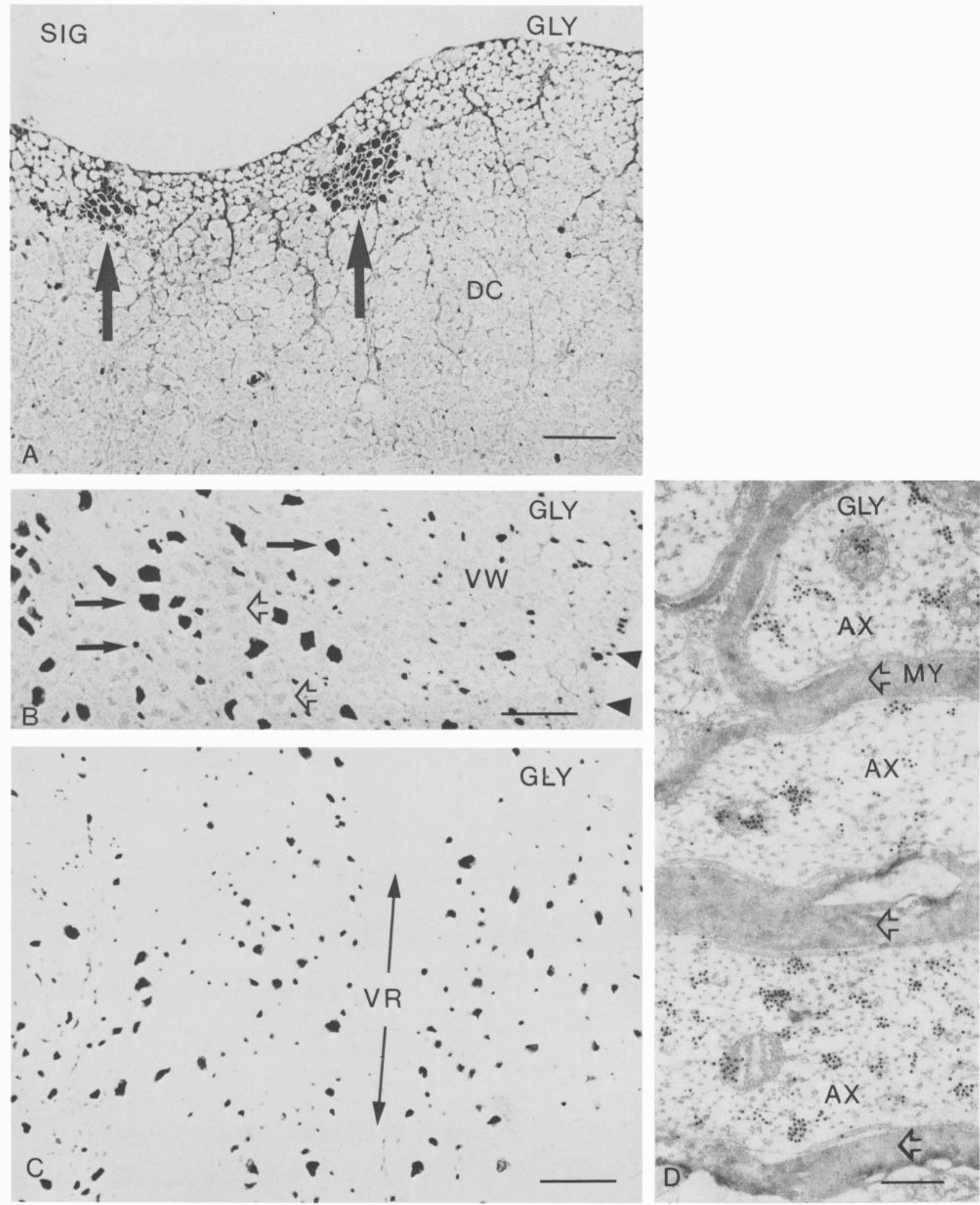

Figure 6. Glycine immunoreactive $(G L Y)$ axons in white matter. Silver-intensified gold $(S I G)$ immunostaining was used to stain glycine-immunoreactive axons in the white matter black. $A$, While the number of axons stained in the dorsal columns is very low compared with the lateral or ventral white matter, small fascicles of axons can be found. Two groups (black arrows) are seen on both sides of the cord and were consistently labeled on serial sections. Scale bar, $20 \mu \mathrm{m}$. $B$, High-magnification light micrograph of large and small immunoreactive axons in the ventral white $(V W)$ matter (black arrows). This section was slightly overstained to show a very low level of staining that can be found in most axons, which may be interpreted either as a low level of antigen or as background staining. Note the apparent absence of immunoreactivity over myelin surrounding the axons here (hollow arrow) and in $A$. Edge of cord is defined by arrowheads. Scale bar, $10 \mu \mathrm{m}$. $C$, In the ventrolateral white matter, glycine immunoreactive-axons are absent from the ventral roots $(V R$, arrow). Scale bar, $15 \mu \mathrm{m}$. $D$, Electron micrograph of axons in the white matter stained for glycine with colloidal gold. Gold particles are seen over axons $(A X)$ but not over the surrounding myelin $(M Y)$. Scale bar, $0.2 \mu \mathrm{m}$. 

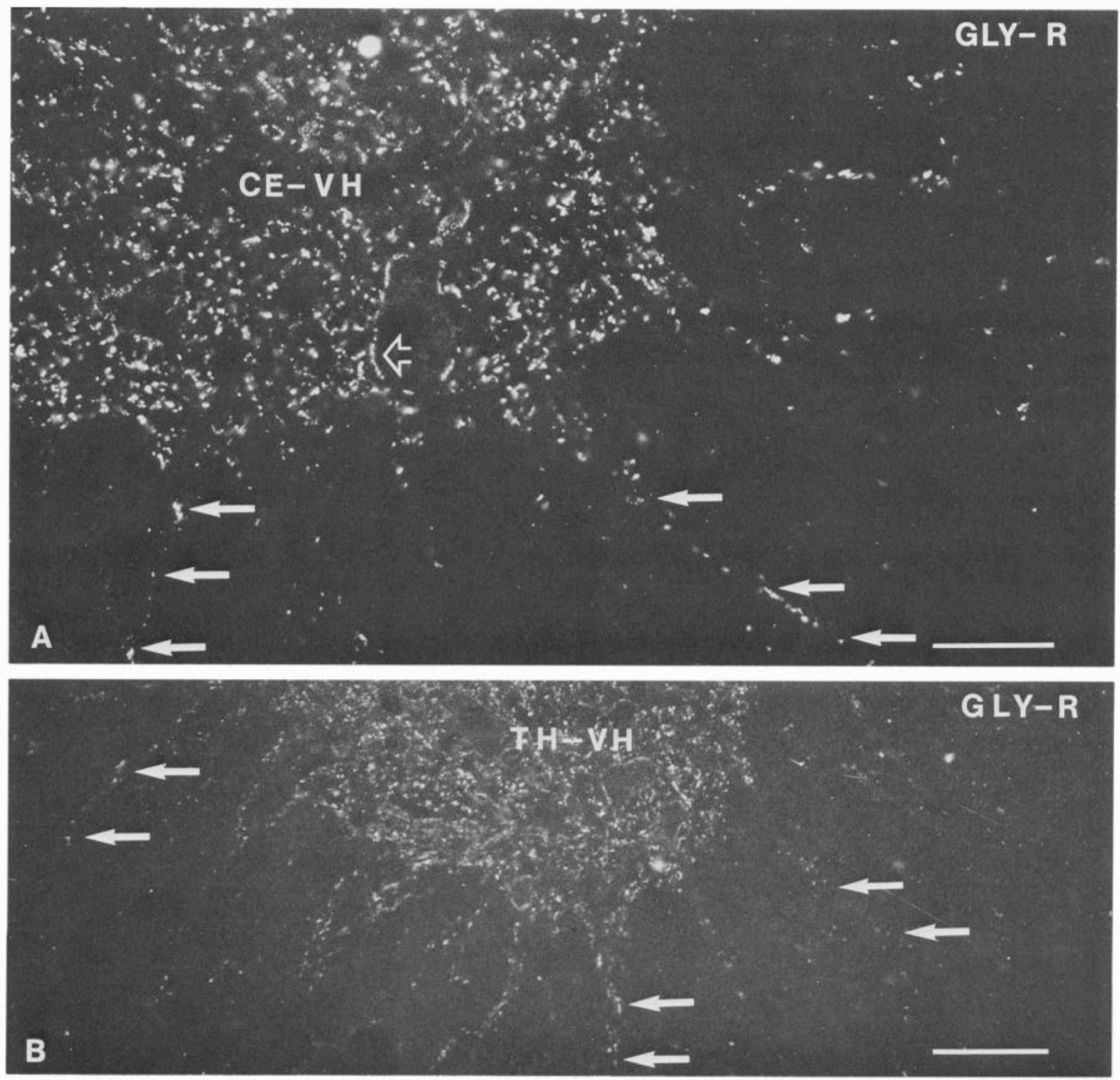

Figure 7. Glycine receptor immunoreactivity $(G L Y-R)$. $A$ and $B$, In the cervical ventral horn $(C E-V H)$ and thoracic ventral horn $(T H-V H)$, large dendrites showing strong glycine receptor immunoreactivity project from the gray matter into the white matter (white arrows). Hollow arrow in $A$ shows immunoreactivity around large neuron. Scale bar: $A, 40 \mu \mathrm{m} ; B, 85 \mu \mathrm{m}$.

ically stained with our antiserum were similar to those we obtained with 2 other affinity-purified antisera raised against glycine conjugated to BSA kindly provided by Dr. R. Wenthold (NIH) and Dr. R. Pourcho (Wayne State University). The specificity of these 2 antisera is described elsewhere (Pourcho and Goebel, 1985; Wenthold et al., 1987).

Spinal cord: primate. Examination of the primate cervical spinal cord stained with antisera against the glycine receptor revealed a staining pattern similar to that found in the rat. Although the receptor density varied in different regions of the cord, the receptor was nonetheless found to be distributed throughout all laminae of the cord. Gly-R immunoreactivity was found both around motor neurons in the ventral horn, as well as throughout the dorsal horn of the cord (Fig. 8A). As with the rat, some gly-R immunoreactivity was found on dendrites that projected into the white matter of the cord (Fig. $8 C$ ). This was most prominent in the ventral lateral white matter. Gly-R immunoreactivity at the distal ends of dendrites in the white matter was more evident in rat than in primate. Immunoreactive dendrites were not observed projecting into the dorsal columns, although the gray matter surrounding the dorsal columns were rich in gly-R immunoreactivity (Fig. $8 B$ ).

\section{Ultrastructural localization of glycine immunoreactivity}

Postembedding immunostaining with colloidal gold revealed glycine immunoreactivity in large numbers of boutons making synaptic contact with neuronal perikarya, and with proximal and distal dendrites in the rat spinal cord (Figs. 9 and 10). The synaptic contact was generally of the symmetrical type. Labeled presynaptic boutons contained flattened vesicles and were rich in mitochondria. While a large number of boutons containing flattened vesicles and making symmetrical synapses were labeled, other boutons with similar morphology in the same thin section were unlabeled. Presynaptic boutons forming asymmetrical synapses showed relatively little immunolabeling with colloidal gold, while adjacent boutons making symmetrical synapses with the same dendrite were often labeled (Fig. 10). Impressive differences were found in the number of gold particles over different axons in the same regions after glycine immunostaining. Some axons were covered with gold particles, while 

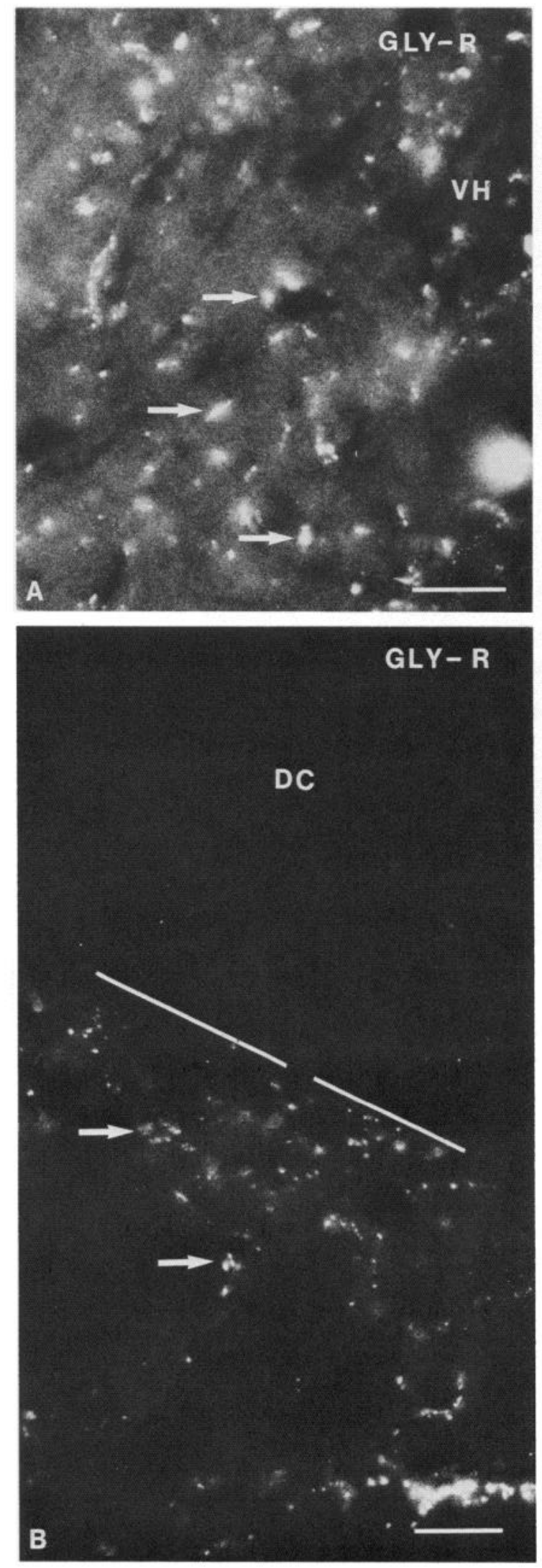

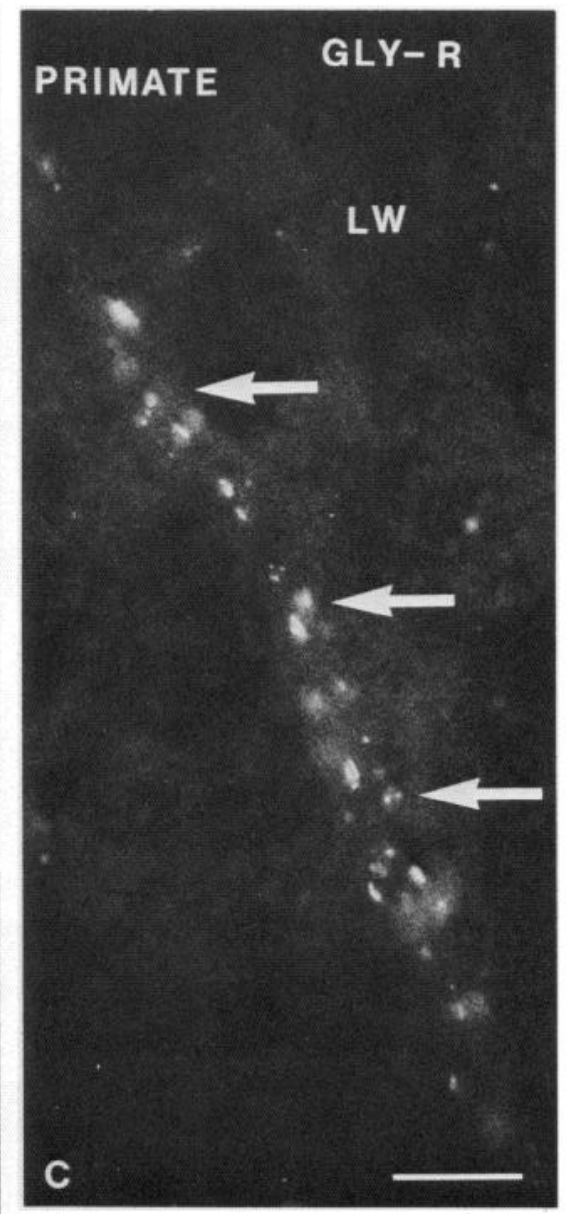

Figure 8. Primate glycine receptor immunoreactivity $(G L Y-R)$. $A$, In the ventral horn $(V H)$, punctate glycine receptor immunoreactivity is found throughout the ventral horn, as shown with immunofluorescence (white arrows). Scale bar, $8 \mu \mathrm{m}$. $B$, While the gray matter surrounding the dorsal column $(D C)$ shows strong glycine receptor immunoreactivity, the dorsal columns themselves are lacking in immunoreactivity. Scale bar, $20 \mu \mathrm{m}$. $C$, As in the rat, long dendrites projecting into the lateral white matter $(L W)$ show glycine receptor immunoreactivity. Scale bar, $15 \mu \mathrm{m}$.

adjacent axons in the same grid square had few or no gold particles, confirming our light microscopic finding with fluorescence and SIG.

Colloidal gold was found in high densities over regions of the presynaptic bouton that were rich in vesicles, and also over cytoplasmic regions of some axons. Gold particles were also located over mitochondria in immunoreactive boutons but in much lower numbers over mitochondria of postsynaptic den- 

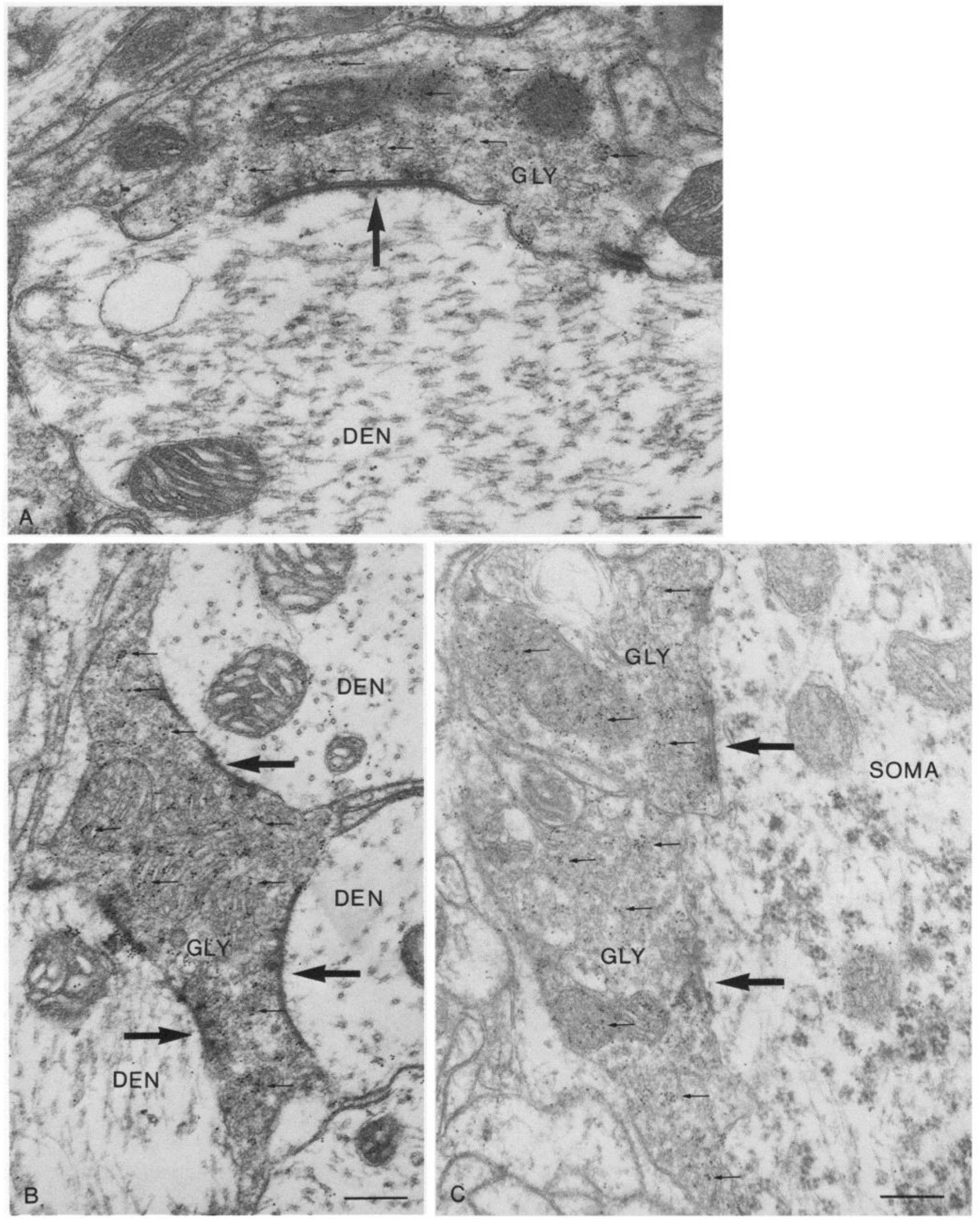

Figure 9. Ultrastructural localization of glycine immunoreactivity $(G L Y)$ detected with colloidal (small arrows) gold. A, Large bouton makes a symmetrical synapse (black arrow) with a large proximal dendrite. Large numbers of small colloidal gold particles cover the presynaptic bouton. Gold is found over regions rich in vesicles. Gold labeling is heavily concentrated over mitochondria in the immunoreactive terminal, but not over mitochondria of the postsynaptic dendrite. $B$, In the dorsal horn a single immunoreactive axon makes synaptic contact with 3 dendrites (black arrows). $C$, In the ventral horn, a large motor neuron soma receives synaptic contact from many immunoreactive boutons, 2 shown here (black arrows). Scale bars, $0.4 \mu \mathrm{m}$. 

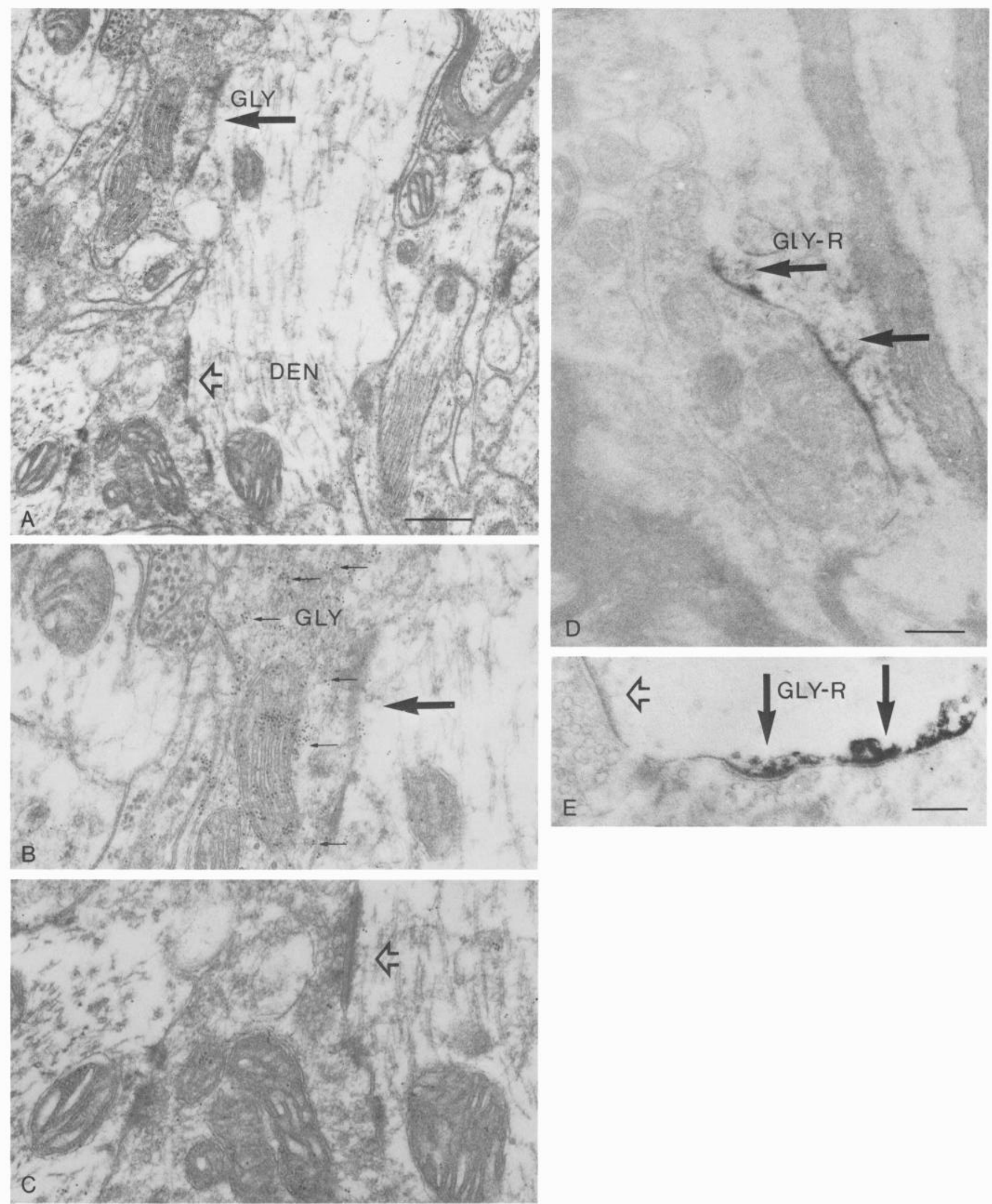

Figure 10. Ultrastructural labeling of symmetrical synapse with glycine immunoreactivity $(G L Y)$ and glycine receptor immunoreactivity $(G L Y$ $R$ ). A, Low-magnification electron micrograph shows a symmetrical (black arrow) and asymmetrical (hollow arrow) synapse on the same dendrite. $B$, Higher-magnification view of $A$ shows a gold-labeled (small arrows) glycine immunoreactive $(G L Y)$ bouton making a symmetrical synapse. $C$, Second bouton making an asymmetrical synaptic contact. This bouton shows little label compared with that in $B$. Scale bar, $0.7 \mu$ m. $D$, Glycine receptor immunoreactivity is stained with peroxidase (arrows) and is located along the intracellular side of the postsynaptic membrane but not 

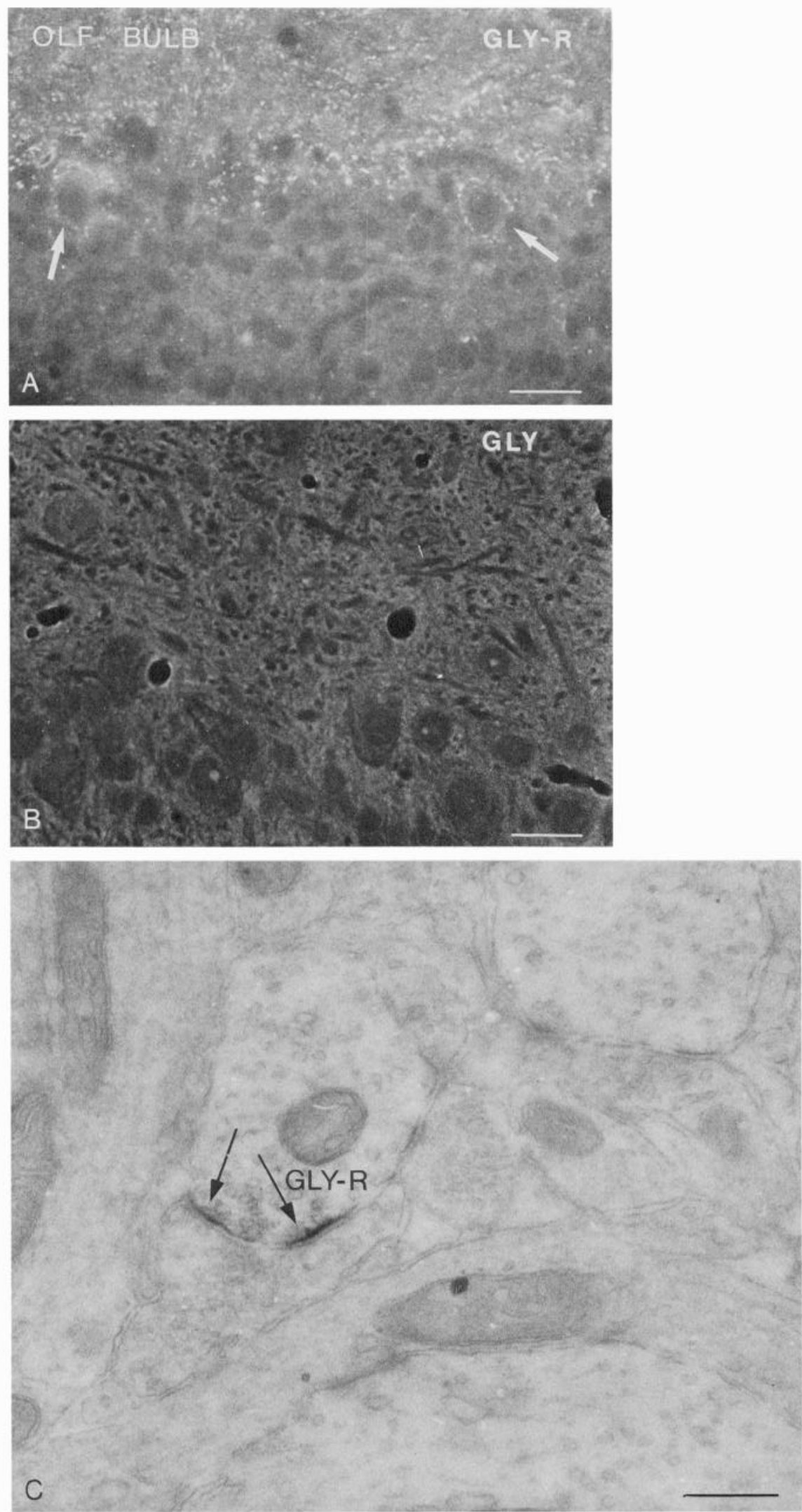

Figure 11. Olfactory bulb. A, Glycine receptor immunoreactivity is found in the external plexiform layer of the bulb and surrounding 2 mitral cells (white arrows). B, Low level of glycine immunoreactivity is seen throughout the external plexiform layer. Scale bar, 35 $\mu \mathrm{m}$. $C$, Electron micrograph of glycine receptor immunoreactivity $(G L Y-R)$ stained with peroxidase in the external plexiform layer of the olfactory bulb. This region of the bulb is rich in dendrodendritic interactions between mitral and granule cells. Peroxidase immunostaining is associated with the postsynaptic membrane of the larger of the 2 profiles, probably a mitral cell. Scale bar, $0.22 \mu \mathrm{m}$.

over other regions of membrane. Scale bar, $0.22 \mu \mathrm{m}$. E, Glycine receptor immunoreactivity shown with peroxidase (black arrows) is along one region of postsynaptic dendrite but is not found associated with an adjacent asymmetrical synapse (hollow arrow) terminating on the same dendrite. Scale bar, $0.18 \mu \mathrm{m}$. To facilitate visualization of the peroxidase immunolabeling of gly-R, tissue shown in $D$ and $E$ is not counterstained with lead citrate or uranyl acetate. 


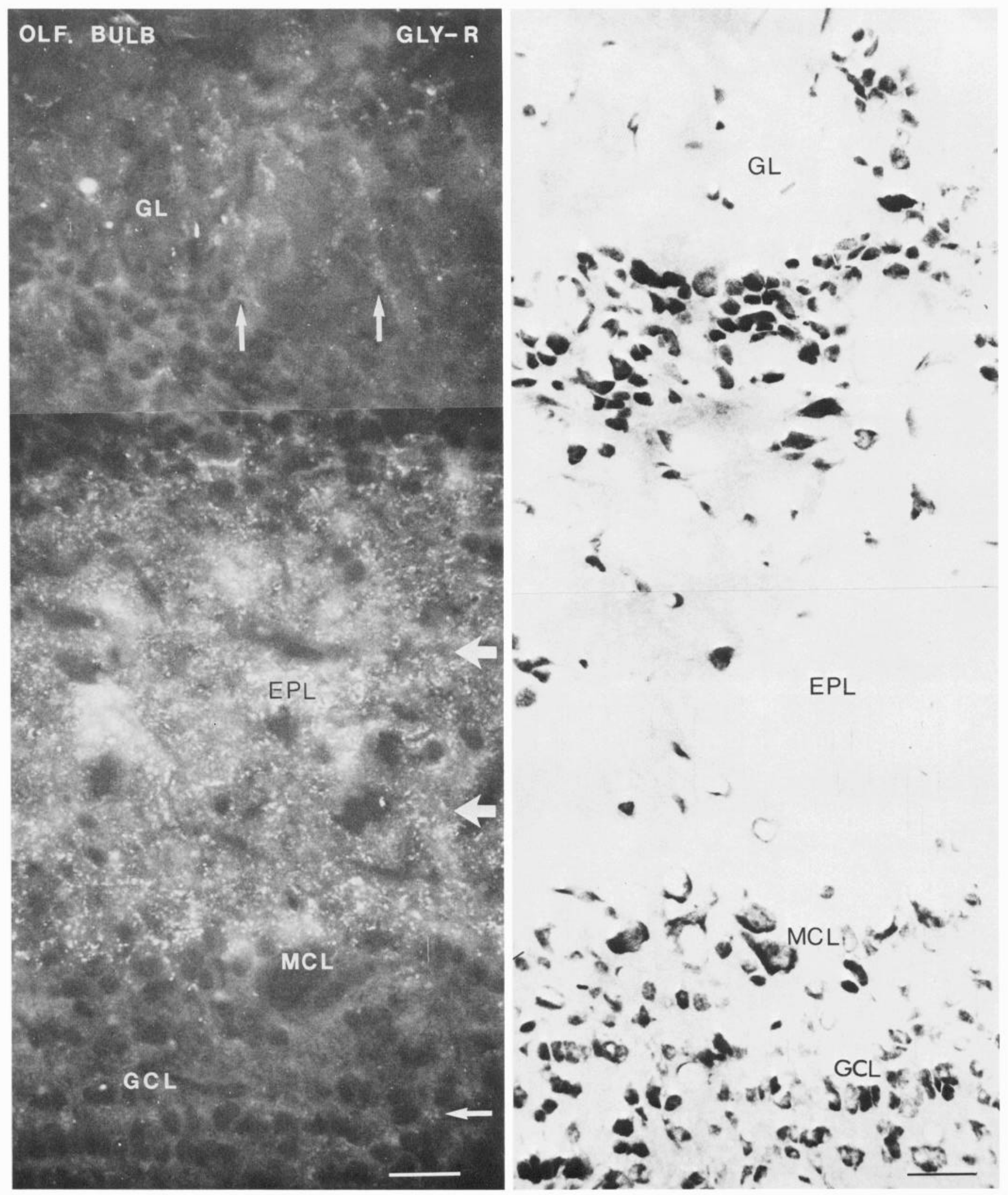

Figure 12. Olfactory bulb. $A$, Strong glycine receptor immunoreactivity $(G L Y-R)$ is found in the external plexiform layer $(E P L)$. Occasional receptors are also found in the glomerular layer $(G L)$ and in the granule cell layer $(G C L)$. $B$, Adjacent Nissl-stained section showing parallel regions to those shown in $A$. Scale bar, $50 \mu \mathrm{m}$. 
drites and cells. This difference was confirmed by comparing the number of gold particles per unit area (measured with a computer-assisted Summagraphics digitizer) over 20 mitochondria in immunoreactive presynaptic boutons with the number of gold particles over 20 mitochondria in cells postsynaptic to immunoreactive boutons. Gold was 15 times more abundant over mitochondria in presynaptic boutons ( $p<0.01 ; t$ test). Mitochondrial labeling was relatively low in boutons making asymmetrical synapses (Fig. 10C).

Glycine receptor immunoreactivity in the cord (detected with monoclonal antibody 7 a) appeared restricted to the cytoplasmic side of membranes postsynaptic to symmetrical synapses (Fig. $10, D, E)$. Nonsynaptic regions of membrane were not stained (Fig. $10 D$ ), and staining was absent from asymmetrical synapses (Fig. 10E).

\section{Other brain areas}

Olfactory bulb. Glycine immunoreactivity was distributed diffusely in neuropil in the external plexiform layer of the olfactory bulb and around the mitral cell bodies (Fig. 11B). Strong gly-R immunoreactivity was found throughout the external plexiform layer and mitral cell body layer but was minimal in the granule cell region, in the white matter at the center of the bulb, and in the glomerular layer (Fig. 12). Despite the low general level of immunoreactivity in the glomerular layer and in the granule cell layer, small numbers of immunoreactive profiles could be found with high-magnification observation. Glycine receptor immunoreactivity appeared to surround cells with the appearance of mitral cells in the mitral cell layer (Fig. 11 $\mathrm{A}$ ). Ultrastructural analysis of peroxidase-stained, glycine-immunoreactive structures revealed labeling in the external plexiform layer associated with synaptic junctions. The labeling was on the cytoplasmic side of postsynaptic regions, with many of the labeled cells identifiable as mitral cells (Fig. 11C).

Other areas of the $C N S$. Only a few glycine-immunoreactive fibers could be found in the hippocampus (Fig. 13A). In contrast, in adjacent sections large numbers of axons were stained with antisera generated against GABA coupled to thyroglobulin; these GABA-immunoreactive axons were found around pyramidal cells and in large numbers around the granule cells in the dentate gyrus. Glycine receptor-like immunoreactivity was found distributed diffusely in the neuropil in the region of pyramidal cell bodies and their apical and basal dendrites (Fig. 13B).

In the cerebellar cortex, glycine-immunoreactive fibers were found in the granule and molecular layers. A few labeled cells were found in the granule layer, and less often a lightly labeled cell was seen in the molecular layer. Purkinje cells and granule cells were not labeled. Glycine-immunoreactive fibers appeared to run along dendrites stretching between the granule cell layer and the outer edge of the cerebellar cortex. Glycine-immunoreactive fibers were much less dense than those stained on adjacent sections with antisera against GABA, and similarly much less dense than glycine staining in the spinal cord. Glycine receptor immunoreactivity appeared evenly spread in the molecular layer and near Purkinje cells (Fig. 13C). The density of gly-R immunostaining of Purkinje cell somata was very low compared with the strong staining found around motor neurons of the spinal cord. Gly-R immunoreactivity was sparse in the granule cell layer (Fig. 13C).

Glycine-immunoreactive fibers could be found in different regions of the hypothalamus. Gly-R immunoreactivity was evident in the magnocellular regions of the supraoptic and paraventricular nucleus and in the mammillary region. Small, weak- ly fluorescent punctate densities could also be found in other regions of the hypothalamus; the intensity of hypothalamic immunostaining was considerably less than that found in the spinal cord.

Glycine receptor immunoreactive profiles in the spinal cord and medulla, identified with either monoclonal antibody 5a or $7 \mathrm{a}$, were intensely stained, numerous, and varied from punctate densities of about $0.3 \mu \mathrm{m}$ to slightly more than $2 \mu \mathrm{m}$. On the other hand, staining in the same brain of cerebellum, hypothalamus, hippocampus, and olfactory bulb was qualitatively different. While retaining the same punctate structure suggestive of postsynaptic localization, the staining intensity with immunofluorescence was much lower in rostral brain areas, and required higher magnification microscope objectives for analysis. The immunoreactive synaptic region appeared smaller in rostral brain areas than in the spinal cord. The general brightness of immunofluorescence in rostral brain regions was significantly less than in the caudal brain and spinal cord.

\section{Discussion}

Amino acid immunocytochemistry

On the basis of immunoblots and ELISA assay, the glycine antiserum used in the present paper appears to have a strong binding affinity for glycine and relatively little to other amino acids. Since immunocytochemical detection of antigens is highly dependent on fixation, and as we were interested in ultrastructural localization, we used a hapten-carrier conjugation procedure involving glutaraldehyde, which is also an excellent fixative for ultrastructural preservation. This type of conjugation was previously used to make antisera against GABA and glutamate (Storm-Mathisen et al., 1983). That we are not looking at some antigenic cross-reaction with the thyroglobulin carrier molecule is supported by use of affinity-purified antisera, with which antibodies cross-reacting with the carrier are greatly reduced. Furthermore, we found the same general immunocytochemical results with 2 antisera from other labs that were raised against glycine conjugated to a different carrier protein, BSA. The strongest cross-reaction of our glycine antiserum was with $\beta$-alanine; when antiserum against $\beta$-alanine was used for immunostaining, it did not stain axons stained in adjacent sections with glycine antiserum.

Unlike GABA, glycine is incorporated into a wide variety of proteins and peptides in cells throughout the brain. However, only in restricted regions of the nervous system do we find substantial immunoreactive glycine, notably in the spinal cord. In contrast, only a small number of axons are stained in the hippocampus with glycine antisera, while a large number are stained with GABA antiserum. While glycine is incorporated into a large number of proteins, our antiserum showed little apparent recognition of glycine incorporated into peptides in our ELISA assay. Since the amino terminal of glycine is conjugated to glutaraldehyde, the lack of recognition of glycine in peptides suggests the antiserum is recognizing the carboxy terminal of the glycine, probably together with glutaraldehyde. The antiserum has relatively little affinity for glutaraldehyde alone since it does not bind to other amino acids conjugated to glutaraldehyde. As with antisera against any antigen, we cannot rule out the possibility that in certain regions of the brain untested determinants exist that cross-react with glycine antisera.

\section{Correlation of immunostaining with other glycine studies}

Biochemical studies (Werman et al., 1967; Aprison et al., 1975) showed that the highest levels of glycine in the cord were in the 

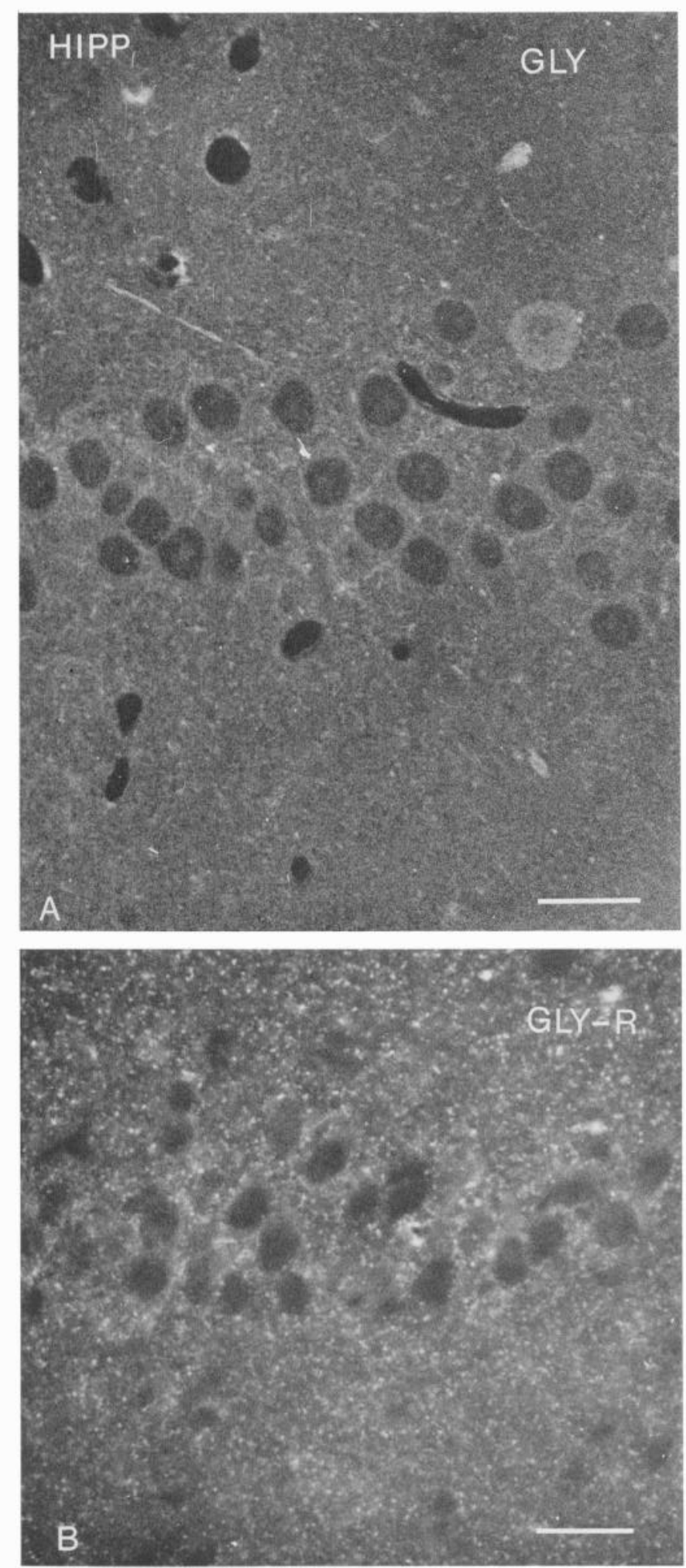

CEREBELLUM

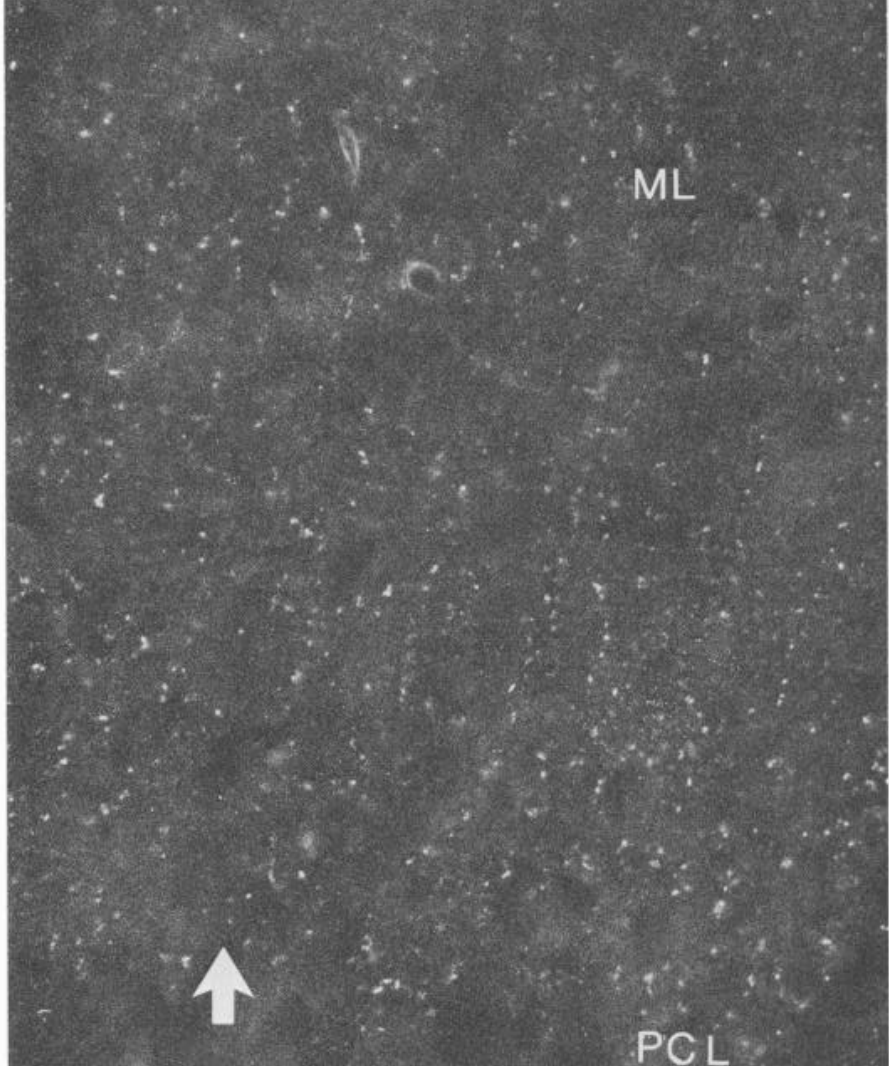

C

Figure 13. A, Hippocampus. A small number of axons weakly stained with glycine antiserum $(G L Y)$ are seen in the region of the pyramidal cell layer. Scale bar, $50 \mu \mathrm{m}$. B , Glycine receptor-like immunoreactivity $(G L Y-R)$ is found around pyramidal cells and the regions of their apical and basal dendrites. The brightness of the immunofluorescent densities in the hippocampus was much less than that found in any region of the cord. Scale bar, $60 \mu \mathrm{m}$. $C$, Cerebellum. Glycine receptor-like immunoreactivity is found predominantly in the molecular layer $(M L)$ and Purkinje cell layer $(P C L)$, while immunoreactivity is rare in the granule layer $(G L)$. Scale bar, $50 \mu \mathrm{m}$. 
central gray matter, with ventral gray having slightly greater amounts of glycine than the dorsal gray. Our results corroborate this. Previous studies also showed that while the levels of glycine in the white matter were less than in the gray matter, considerable amounts of glycine were nevertheless found in the white matter, with lowest levels found in the dorsal columns (Davidoff et al., 1967; Aprison et al., 1969). Similarly, we find that the greatest amount of glycine immunoreactivity is in the lateral and ventral white, with the least in the dorsal columns. Furthermore, our data based on fluorescent, light, and electron microscopy indicate that glycine immunoreactivity is not evenly distributed among all axons of a region, but rather occurs in high concentrations in specific axons and is not detectable in others.

After temporary aortic occlusion, glycine in both the gray and white matter decreased, as did the number of small, presumed interneurons in the gray matter. The decrease of glycine in white matter has been attributed to a loss of propriospinal neurons (Davidoff et al., 1967). In our study, glycine immunoreactivity is found not only in small axons near the perimeter of the gray matter, where propriospinal axons might be expected (Davidoff et al., 1967), but also in large and myelinated axons in varying densities throughout the lateral and ventral white matter. Our data are consistent with the involvement of glycine in local propriospinal function, but they also suggest that other systems may contain high levels of glycine. Previous work has shown strong labeling of some myelinated axons after incubation of cord slices with radiolabeled glycine (Hökfelt and Ljungdahl, 1975). Evidence for long ascending or descending glycinergic tracts is provided by physiological studies. The action of descending fibers from the medial vestibular nucleus which make inhibitory monosynaptic connections with motor neurons in the cervical cord (Wilson and Yoshida, 1969) was blocked by the glycine antagonist strychnine but not by the GABA antagonists bicuculine and picrotoxin (Felpel, 1972). Similarly in the brain, lateral hypothalamic cells were inhibited by glycine, while the inhibitory projection from the frontal cortex to the lateral hypothalamus was blocked by strychnine (Kita and Oomura, 1982).

The use of antibodies against glycine receptors complements the use of antisera directed against glycine. Glycine receptor immunoreactivity was found throughout both rodent and primate spinal cord gray matter. The monoclonal antisera against the glycine receptor have been tested extensively against spinal cord homogenates, and they appear to recognize a single receptor type. Furthermore, the glycine receptor antibodies do not appear to cross-react significantly with purified GABA receptors $(H$. Betz, personal communication). However, the possibility cannot yet be excluded that in rostral brain areas there may be other antigens with which the monoclonals cross-react. Arguing against this is the finding that antibodies derived from 2 different B-lymphocyte clones (Pfeiffer et al., 1984), and which stain slightly different morphological regions of the same synapse (Triller et al., 1985), show a similar distribution of staining in the spinal cord and cerebellum. Additionally, the staining pattern in more rostral brain areas, although differing in intensity, still retains the same basic punctate appearance with light microscopy as in the cord, where it is associated with the postsynaptic specialization. In the olfactory bulb, we confirmed the association of glycine receptor immunoreactivity with synapses. However, further ultrastructural and biochemical studies are needed in the bulb and in other areas of the brain to confirm that the immunoreactivity seen is indeed glycine receptor protein.

\section{Subcellular localization of glycine immunoreactivity}

A high density of glycine immunolabeling with colloidal gold was found predominantly over some boutons making symmetrical synaptic contact but not over those making asymmetrical synaptic contact. In a parallel fashion, glycine receptor immunostaining with peroxidase was associated with membrane postsynaptic to some symmetrical synapses, providing suggestive evidence that if glycine is released, it would probably be from terminals showing intense glycine immunoreactivity which make symmetrical type synapses. Our ultrastructural data showing strong glycine immunoreactivity in specific boutons are consistent with previous ultrastructural autoradiography studies of glycine uptake into axonal boutons (Hökfelt and Ljungdahl, 1971; Matus and Dennison, 1971; Iverson and Bloom, 1972). One previous report suggested high-affinity uptake of glycine into myelin (Valdes et al., 1977); in contrast, we did not find strong immunolabeling of myelin. The low level of glycine immunostaining found throughout the tissue may indicate the presence of small concentrations of glycine in neurons using this amino acid for protein synthesis or other metabolic functions.

The present data do not address the question of whether glycine is located inside the small clear vesicles characteristic of glycine-immunoreactive boutons; only a vesicle where the interior of the vesicle was recognizable and exposed to the surface of the thin section would be labeled, and given the size of the vesicles, the sizes of the immunoglobulins and gold particles, such an analysis is not straightforward. Mitochondria in axon terminals containing vesicle regions not labeled with gold were similarly unlabeled. Our immunocytochemical localization of glycine in mitochondria of some axon terminals is consistent with previous autoradiographic and biochemical studies showing localization of tritiated glycine in mitochondria (Aprison et al., 1975; Price and McAdoo, 1981). One of the characteristic features of presynaptic glycine-immunoreactive boutons is the relatively large number of mitochondria. Mitochondria may play a crucial role in glycine availability for neurotransmission. Serine, which has been considered an important precursor for glycine, is found in mitochondria; mitochondria isolated from the nervous system take up radiolabeled serine from the surrounding media and release radiolabeled glycine (Aprison et al., 1975). An additional explanation for the immunolabeling of some mitochondria may be that more glutaraldehyde binding sites may be found in mitochondria, allowing a higher level of glycine binding during fixation in axons containing high concentrations of this amino acid.

\section{Correlation of glycine and glycine receptor immunoreactivity}

Do glycine immunoreactive axons and glycine receptors always occur in the same region? In the spinal cord, every lamina contains both glycine-immunoreactive axons and immunoreactive glycine receptors. The density of immunoreactive glycine varies between laminae, and this density is paralleled by the intensity of staining for immunoreactive glycine receptors. In the dorsal region of the cord, strong labcling with antiscra against both glycine and glycine receptors was found in the deeper parts of the dorsal horn, consistent with a previous report indicating the highest grain density after autoradiographic studies of tritiated glycine was over deeper laminae of the dorsal horn (RibeiroDa Silva and Coimbra, 1980). Immunolabeling of laminae 1 and 2 was also noted in cord segments in the present study, but the number of immunoreactive profiles was less than in the 
deeper dorsal horn. The greatest intensity of staining for both glycine and glycine receptor was in the ventral horn.

With radioactive strychnine binding, strong labeling was found in the gray matter of the spinal cord and in a number of other regions, particularly in the caudal part of the nervous system (Zarbin et al., 1981; Probst et al., 1986); no appreciable binding was rcported in the olfactory bulb or in the cerebellum, a region where we firid both glycine-immunoreactive axons and glycineimmunoreactive receptors. This apparent discrepancy may be due to a slightly higher sensitivity of the immunostaining method used here for detecting small numbers of immunoreactive profiles, combined with the high magnification analysis used for detecting lower levels of receptor.

In the olfactory bulb, we find an intense immunoreactivity for glycine receptors in the external plexiform layer, a neuropil region containing many presynaptic mitral cell and granule cell dendrites. Our data suggest that the immunoreactivity is associated with mitral cells, possibly postsynaptic to granule cell presynaptic dendrites. Glycine-immunoreactive profiles are found throughout the external plexiform layer, coextensive with glycine receptors, as well as in other laminae of the bulb. Glycine-immunoreactive axons are also found in the glomerular layer, as are a few faintly labeled perikarya. The distribution of glycine immunolabeling was similar to that described for glycine uptake (Halasz et al., 1979).

As in the olfactory bulb, the localization of glycine receptorlike immunoreactivity in the cerebellum is restricted to one laminar region of the molecular and Purkinje cell layer. Glycine receptor immunoreactivity was absent or very low in the granule layer. In contrast, glycine-immunoreactive perikarya appeared most numerous in the granule layer in cells with the appearance of Golgi cells, consistent with previous reports of glycine uptake restricted to some Golgi cells in the granule layer (Wilkin et al., 1981). As the axons of Golgi cells innervate the granule cells in the same layer, the origin of the fibers presynaptic to the glycine receptor immunoreactivity in the molecular layer is unclear. Occasional stellate cells show a dim glycine immunoreactivity and may serve as a source for glycine containing boutons. Alternatively, an input from cells outside of the cerebellar cortex may contribute a glycinergic innervation. Previous studies have shown that the Golgi cells contain GABA and glutamate decarboxylase and take up tritiated glycine or GABA (Wilkin et al., 1981). That certain cells may contain detectable amounts of both glycine and GABA in the cerebellum (Storm-Mathisen et al., 1986), auditory system (Wenthold et al., in press), and spinal cord (van den Pol and Gorcs, 1986) has recently been suggested and merits further experimental consideration.

\section{Heterogeneity of glycine receptor immunoreactivity}

Glycine receptor immunoreactivity was particularly strong in the spinal cord, while in more rostral regions of the brain such as the olfactory bulb, cerebellum, hypothalamus, or hippocampus, the staining intensity was greatly reduced. The reduction in staining intensity in rostral brain regions compared with the spinal cord was due both to a decrease in the number of stained profiles and to a decrease in the intensity of staining of individual profiles. Since the structures stained with antisera used in the present study are regions of the postsynaptic specialization (auditory system: Altschuler et al., 1986; spinal cord: Triller et al., 1985 and present study; olfactory bulb: present study), smaller synaptic specializations would result in a smaller fluorescent signal. This receives support from our obscrvation not only that many of the presynaptic glycine-immunoreactive boutons, particularly in the ventral horn, are large, but also that a single axon may make a number of synapses in close proximity, leading to a large region of postsynaptic specialization. An alternative, but not mutually exclusive, explanation is that there are fewer glycine receptors per synapse in more rostral regions of the brain compared with spinal cord. Finally, although all tests to date (Pfeiffer et al., 1984; Triller et al., 1985) suggest that the glycine receptor antisera are specific, CNS regions outside the cord have not been tested as thoroughly as the cord, and some undetermined substance may cross-react.

\section{Motor control}

With light microscopy, it appeared that every motor neuron examined either was surrounded by glycine-immunoreactive fibers or had punctate immunoreactivity for glycine receptor antisera. Ultrastructural studies with colloidal gold indicated that many glycine-immunoreactive boutons were in synaptic contact with these large cells. Similarly, previous studies after administration of tritiated glycine to cord slices in vitro or after in vivo injections showed strong labeling of axonal endings (Hökfelt and Ljundahl, 1971; Matus and Dennison, 1971; Ljungdahl and Hökfclt, 1973). In contrast to a recent report (Campistron et al., 1986), we did not find any appreciable glycine immunoreactivity in large motoneurons of the ventral horn; similar parallel experiments with uptake of tritiated glycine failed to find strong glycine uptake in motor neurons (Ljungdahl and Hökfelt, 1973). On the other hand, we did find smaller neurons in the ventral horn that were stained with glycine antiserum. If some of these cells are Renshaw cells, which mediate collateral inhibition from motor neurons, it will be useful to undertake further ultrastructural examinations to determine if apparent contacts between immunoreactive boutons and cells seen on $0.5-\mu \mathrm{m}$-thick sections are synaptic in nature. If so, this would be consistent with previous physiological data that Renshaw cells may be inhibited by glycine (Curtis et al., 1968). Glycine may then function as a Renshaw cell transmitter inhibiting motor neurons, and also as a transmitter released by unidentified neurons which could inhibit the Renshaw cells, indirectly increasing the activity of motor neurons.

\section{A neurotransmitter role for glycine}

In the present paper we have presented data showing restricted distributions of glycine; many axonal boutons and a number of cells were immunolabeled. Converging lines of evidence suggest that glycine is released by neurons (Mulder and Snyder, 1974), that it can be removed from the extracellular space by an active uptake process (Neal and Pickles, 1969; Neal, 1971), and that the majority of glycine taken up by cells of the rat spinal cord is retained as free glycine (Price et al., 1976). Furthermore, regions of the CNS that normally contain large amounts of endogenous glycine are also those that show the greatest uptake of glycine into slices (Neal, 1971), consistent with a hypothesis of inactivation of glycine by reuptake. Experimentally applied glycine can depress the electrical activity of neurons, mimicking the activity of the natural transmitter, and this depression can be selectively blocked by strychnine (Werman et al., 1967; Curtis et al., 1968; Johnson et al., 1970). The addition of the present data demonstrating high amounts of glycine in a select population of presynaptic axons further supports the role of glycine as a neurotransmitter candidate.

Taken together, the present studics combining immunocy- 
tochemical localization of the amino acid glycine and of glycine receptors in restricted locations in the same regions of the spinal cord provide additional evidence that glycine may be an important neurotransmitter in these regions. The widespread distribution of glycine and its receptor in both the ventral and dorsal horns of the cord suggest that glycine may play a role both in control of movement in the ventral horn and sensory perception and nociception in the dorsal horn. In fact, the distribution of glycine and its receptor is so widespread in the spinal cord that it is conceivable that glycine may play a role in most circuits and functions of the spinal cord. The only other neurotransmitter in the spinal cord with such a strong and widespread distribution is GABA (Barber et al., 1982); electrophysiological experiments suggest that spinal cord neurons-including motor neurons, Renshaw cells, and dorsal horn neurons-are all more responsive to glycine than GABA, while the reverse is true in the cerebral cortex (Curtis et al., 1968). The data presented here suggest that glycine and its receptor are more restricted in their distribution in rostral brain areas investigated, yet may still occur in a larger number of systems than previously considered.

\section{References}

Altschuler, R. A., H. Betz, M. H. Parakkal, K. A. Reeks, and R. J. Wenthold (1986) Identification of glycinergic synapses in the cochlear nucleus through immunocytochemical localization of the postsynaptic receptor. Brain Res. 369: 316-320.

Aprison, M. H., R. P. Shank, and R. A. Davidoff (1969) A comparison of the concentration of glycine, a transmitter suspect, in different areas of the brain and spinal cord in seven different vertebrates. Comp. Biochem. Physiol. 28: 1345-1355.

Aprison, M. H., E. C. Daly, R. P. Shank, and W. J. McBride (1975) Neurochemical evidence for glycine as a transmitter and a model for its intrasynaptosomal compartmentation. In Metabolic Compartmentation and Neurotransmission-Relation to Brain Structure and Function, S. Berl, D. D. Clarke, and D. Schneider, eds., pp. 37-89, Plenum, New York.

Barber, R. P., J. E. Vaughn, and E. Roberts (1982) The cytoarchitecture of GABAergic neurons in rat spinal cord. Brain Res. 238: 305-328.

Campistron, G., R. Buijs, and M. Geffard (1986) Glycine neurons in the brain and spinal cord. Antibody production and immunocytochemical localization. Brain Res. 376: 400-405.

Curtis, D. R., L. Hosli, and G. A. R. Johnston (1968) A pharmacological study of the depression of spinal neurones by glycine and related amino acids. Exp. Brain Res. 6: 1-18.

Davidoff, R. A., L. T. Graham, R. P. Shank, R. Werman, and M. H. Aprison (1967) Changes in amino acid concentrations associated with loss of spinal interneurons. J. Neurochem. 14: 1025-1031.

De Camilli, P., R. Cameron, and P. Greengard (1983) Synapsin 1 (Protein 1), a nerve terminal-specific phosphoprotein. 1. Its general distribution in synapses of the central and peripheral nervous system demonstrated by immunofluorescence in frozen and plastic sections. J. Cell Biol. 96: 1337-1354.

Felpel, L. P. (1972) Effects of strychnine, bicuculline and picrotoxin on labrinthine-evoked inhibition in neck motoneurons of the cat. Exp. Brain Res. 14: 494-502.

Halasz, N., A. Ljungdahl, and T. Hökfelt (1979) Transmitter histochemistry of the rat olfactory bulb. III. Autoradiographic localization of $\left[{ }^{3} \mathrm{H}\right]$ GABA. Brain Res. 167: 221-240.

Hökfelt, T., and A. Ljungdahl (1971) Light and electron microscopic autoradiography on spinal cord slices after incubation with labeled glycine. Brain Res. 32: 189-194.

Hökfelt, T., and A. Ljungdahl (1975) Uptake mechanisms as a basis for the histochemical identification and tracing of transmitter-specific neuron populations. In The Use of Axonal Transport for Studies of Neuronal Connectivity, W. M. Cowan and M. Cuenod, eds., pp. 249305, Elsevier, New York.

Hsu, S., L. Raine, and H. Fanger (1981) Use of avidin-biotin-peroxidase complex $(\mathrm{ABC})$ in immunoperoxidase techniques: $\mathrm{A}$ com- parison between $\mathrm{ABC}$ and unlabeled antibody (PAP) procedures. J. Histochem. Cytochem. 29: 577-580.

Johnson, E. S., M. H. T. Roberts, and D. W. Straughan (1970) Amino acid induced depression of cortical neurones. Br. J. Pharmacol. 38; 659-666.

Kita, H., and Y. Oomura (1982) Evidence for a glycinergic corticolateral hypothalamic inhibitory pathway in the rat. Brain Res. 235: 131-136.

Ljungdahl, A., and T. Hökfelt (1973) Autoradiographic uptake patterns of $\left[{ }^{3} \mathrm{H}\right]$ gaba and $\left[{ }^{3} \mathrm{H}\right]$-glycine in central nervous tissues with special reference to the cat spinal cord. Brain Res. 62: 587-595.

Matus, A. I., and M. E. Dennison (1971) Autoradiographic localisation of tritiated glycine at "flat-vesicle" synapses in spinal cord. Brain Res. 32: 195-197.

Maxwell, M. H. (1978) Two rapid and simple methods for the removal of resins from $1.0 \mu \mathrm{m}$ thick epoxy sections. J. Microsc. (Lond.) 112 . 253-255.

Mulder, A. H., and S. H. Snyder (1974) Potassium-induced release of amino acids from cerebral cortex and spinal cord slices of the rat. Brain Res. 76: 297-308.

Neal, M. J. (1971) The uptake of [14C] glycine by slices of mammalian spinal cord. J. Physiol. (Lond.) 215: 103-117.

Neal, M. J., and H. G. Pickles (1969) Uptake of $14 \mathrm{C}$ glycine by spinal cord. Nature 222: 679-680.

Pfeiffer, F., D. Graham, and H. Betz (1982) Purification by affinity chromatography of the glycine receptor of rat spinal cord. J. Biol. Chem. 257: 9389-9393.

Pfeiffer, F., R. Simler, G. Grenningloh, and H. Betz (1984) Monoclonal antibodies and peptide mapping reveal structural similarities between the subunits of the glycine receptor of rat spinal cord. Proc. Natl. Acad. Sci. USA 81: 7224-7227.

Pourcho, R. G., and D. J. Goebel (1985) Immunocytochemical demonstration of glycine in retina. Brain Res. 348: 339-342.

Price, C. H., and D. J. McAdoo (1981) Localization of axonally transported $[3 \mathrm{H}]$ glycine in vesicles of identified neurons. Brain Res. 219: 307-315.

Price, D. L., A. Stocks, J. W. Griffin, A. Young, and K. Peck (1976) Glycine-specific synapses in rat spinal cord. J. Cell Biol. 68: 389-395.

Probst, A., R. Cortes, and J. M. Palacios (1986) The distribution of glycine receptors in the human brain. A light microscopic autoradiographic study using [3H] strychnine. Neuroscience 17: 11-35.

Rexed, B. (1954) A cytoarchitecture atlas of the spinal cord in the cat. J. Comp. Neurol. 100: 297-379.

Ribeiro-Da Silva, A., and A. Coimbra (1980) Neuronal uptake of [3H] glycine in laminae I-III (Substantia gelatinosa rolandi) of the rat spinal cord. An autoradiographic study. Brain Res. 188: 449-464.

Schmitt, B., P. Knaus, C. M. Becker, and H. Betz (1987) The $M_{r}$ 93,000 polypeptide of the postsynaptic glycine receptor complex is a peripheral membrane protein. Biochemisry 26: 805-811.

Somogyi, P., and A. J. Hodgson (1985) Antiserum to gamma amino butyric acid. III. Demonstration of GABA in Golgi-impregnated neurons and in conventional electron microscopic sections of cat striate cortex. J. Histochem. Cytochem. 33: 249-257.

Somogyi, P., and H. Takagi (1982) A note on the use of picric acidparaformaldehyde-glutaraldehyde fixation for correlated light and electron microscopic immunocytochemistry. Neuroscience 7: 17791783.

Storm-Mathisen, J., A. K. Leknes, A. T. Bore, J. L. Vaaland, P. Edminson, F. M. Haug, and O. P. Ottersen (1983) First visualization of glutamate and gaba in neurones by immunocytochemistry. Nature 301: 517-520.

Storm-Mathisen, J., O. P. Ottersen, and S. Davanger (1986) The immunocytochemical demonstration of small transmitter molecules: Visualization of glycine in inhibitory neurons. Soc. Neurosci. Abstr. 12: 771 .

Triller, A., F. Cluzeaud, F. Pfeiffer, H. Betz, and H. Korn (1985) Distribution of glycine receptors at central synapses: An immunoelectron microscopy study. J. Cell Biol. 101: 683-688.

Valdes, F., C. Munoz, A. Feria-Velasco, and F. Orrego (1977) Subcellular distribution of rat brain cortex high affinity, sodium dependent glycine transport sites. Brain Res. 122: 95-112.

van den Pol, A. N. (1984) Colloidal gold and biotin-avidin conjugates as ultrastructural markers for neural antigens. Q. J. Exp. Physiol. 69: 1-33.

van den Pol, A. N. (1985a) Dual ultrastructural localization of two 
neurotransmitter-related antigens: Colloidal gold labeled neurophysin immunoreactive supraoptic neurons receive peroxidase labeled glutamate decarboxylase or gold labeled GABA immunoreactive synapses. J. Neurosci. 5: 2940-2954.

van den Pol, A. N. (1985b) Silver-intensified gold and peroxidase as dual ultrastructural immunolabels for pre- and postsynaptic neurotransmitters. Science 228: 332-335.

van del Pol, A. N. (1986) Tyrosine hydroxylase immunoreactive neurons throughout the hypothalamus receive glutamate decarboxylase immunoreactive synapses: A double pre-embedding immunocytochemical study with particulate silver and HRP. J. Neurosci. 6:877891.

van den Pol, A. N., and T. Gorcs (1986) Glycine immunoreactive neurons and presynaptic boutons in the spinal cord. Soc. Ncurosci. Abstr. 12: 771.

Wenthold, R. J., D. Huie, R. A. Altschuler, and K. A. Reeks (1987)
Glycine immunoreactivity localized in the cochlear nucleus and superior olivary complex. Neuroscience 22: 897-912.

Werman, R., R. A. Davidoff, and M. H. Aprison (1967) Inhibition of motoneurons by iontophoresis of glycine. Nature 214: 681-683.

Wilkin, G. P., A. Csillag, R. Balazs, A. E. Kingsbury, J. E. Wilson, and A. L. Johnson (1981) Localization of high affinity [3H] glycine transport sites in the cerebellar cortex. Brain Res. 216:11-33.

Wilson, V. J., and M. Yoshida (1969) Monosynaptic inhibition of neck motoneurons by the medial vestibular nucleus. Exp. Brain Res. 9: 365-380.

Young, A. B., and S. H. Snyder (1974) Strychnine binding in rat spinal cord membranes associated with the synaptic glycine receptor: Cooperativity of glycine interactions. Mol. Pharmacol. 10:790-809.

Zarbin, M. A., J. K. Wamsley, and M. J. Kuhar (1981) Glycine receptor: Light microscopic autoradiographic localization with $[3 \mathrm{H}]$ strychnine. J. Neurosci. 5: 532-547. 